\title{
Rock Carvings of Armenia
}

\section{K. S. Tokhatyan}

Institute of History of NAS RA, Armenia

Rock-art in Armenia began in the Neolithic period, reaching its peak during the Bronze Age. Rock-carvings have great cognitive value as a cultural source. Their role is important for revealing the historical realities of the Armenian Highland in VII-I millennium BC, to determine the origins of the Armenian people and demographic processes.

Their great number, themes, style and variety testify the sacralized attitude of our ancestors to the rock-art sphere.

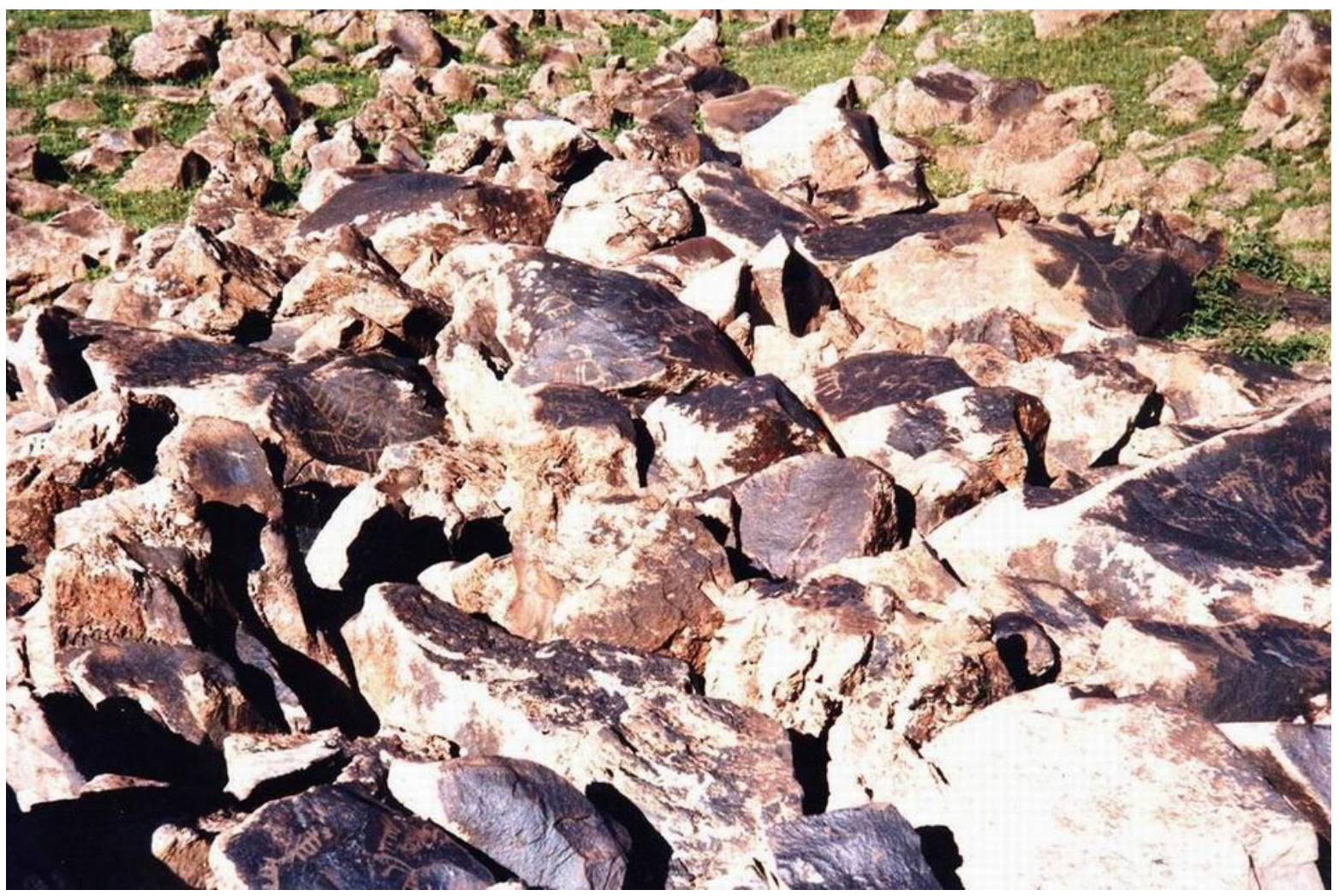

A group of petroglyphs in Geghama Mountains

The petroglyphs of Armenia, by their great number, variety of styles and rich content occupy a unique place in our cultural heritage in the Ancient World.

There are not many petroglyphs adjacent to the Armenian Highland regions, while in the Highland their high concentration is observed, as well as thematic and typological diversity.

The main part of the ancient etched petroglyphs is located at altitudes up to 
$3300 \mathrm{~m}$ a.s.l., but they are also preserved in the foothills and valleys. The ancient inhabitants of Armenia have created huge galleries, mountain sanctuaries, consisting of tens of thousands drawings. There are also found vishaps (stonedragons), summer open-air sites, caves, huge cromlechs, etc nearby the petroglyphs. Such a variety of monuments indicates that the petroglyphs are not isolated phenomena of high mountains, but part of the historical and cultural environment, formed as a result of the human vigorous activity.
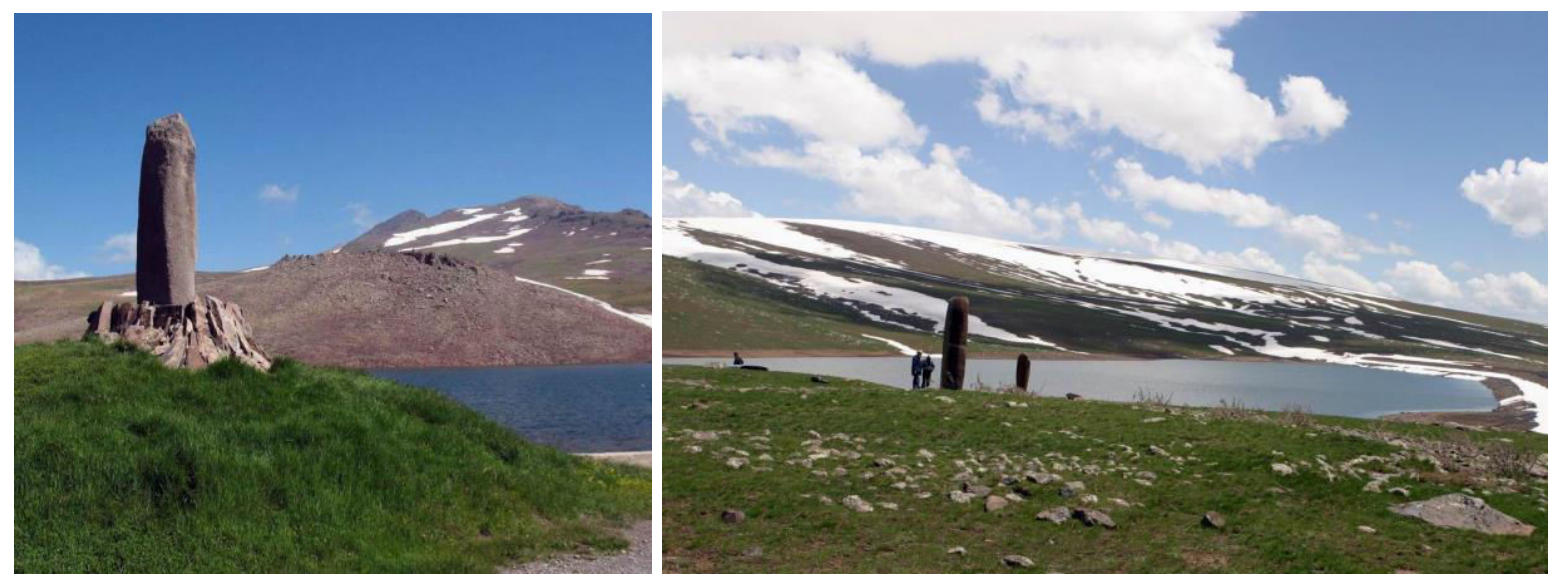

Vishaps /dragon-steles/ on Aragats and Geghama mountains

Location. On the territory of the Republic of Armenia petroglyphs are found in Aragatzotn (Agarak, the SE slopes of Aragats, Aruch, Geghamavan, Ernjatap, Kaqavadzor, Aragatsotn, Mastara, Shamiram, Old Shenik, Voskehat, Tghmut, Quchak, Oshakan), in Armavir (Metsamor, Armavir, St. Gayane, St. Hripsime,), in Gegharquniq (Lchashen, Sevsar, Vardenik, Vardenyats pass, Vardenis Ridge), in Yerevan (Avan), in Lori (Loriberd, Koges, Neghuts), in Kotayq (Balahovit, Bjni, Geghama Ridge, Geghard, Zovuni, Ptghnavanq), in Shirak (Yereruyq, Haykadzor, Horom, Dzithanqov), in Syunik (Zoratsqar, Tzghuk-Ukhtasar, Jermajur), in Vayotsdzor (Teqsar, nearby of the headwaters of rivers Arpa and Yeghegis, Sartsali, in Tavush (Gosh).

In the Artsakh Republic petroglyphs are on the outskirts of Shushi and near the village of Tandzatap, in Karvachar area - in Eghtsategh, on the slopes of the mountains Erakatar, Harsnakar, Ishkhanasar, and Lulpar, on the banks of lakes Tsalq, Sev, and Al.

Petroglyphs have been found to the east from Javakhk in the area of Tsalka, in Nakhichevan - near ancient settlements Astapat, St. Mariam, Paraka and on the west slopes of Navasar. The oldest rock-carvings are known on the west shore of the Caspian Sea, on the Apsheron peninsula and in Gobustan area, which at certain stages of history were part of the Great Armenia, or were in the sphere of its 
influence.

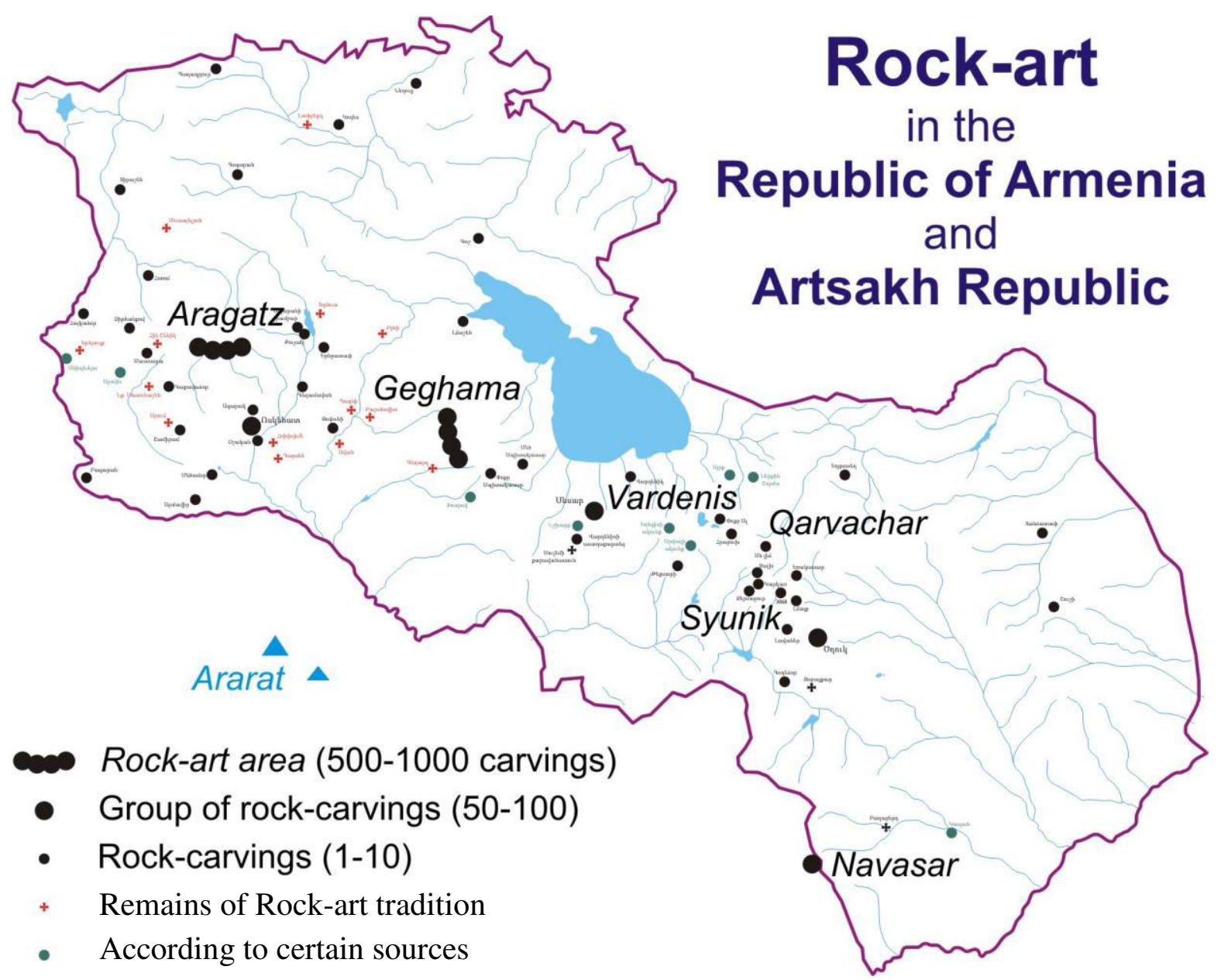

In Western Armenia many Rock-art sites are known: nearby of headwaters of Aratsani river, Azat, Zarishat (in Vanand), Gomshut (in Kaghzvan), Tsolakert on the northern slope of Mt. Ararat-Masis, in the east of Vaspurakan - on the right bank of the Araks river (Araksberan, Vanestan, Songun) and in the vicinity of the river Tghmut (Bastam), the western shore of Kaputan Lake (mountain Zambil), near Van Lake - Andzav, Artamet, Buth, Gaytis, Haykaberd, Marvana, Nar, the citadel of Van, Pakan, Ororan. A huge cluster of petroglyphs has been found in Shatakh mountains - in Tirishin, and in Jogha Mountains - Gavarak, Sat, Sev Ler. They are also in Alki (in Korduq), in Armenian Mesopotamia, and in the west of the Armenian Highland (Adyaman, Aryutsablur, Bagarich, Partizak, Malatya, Portablur, Kharberd), and in the SE of Cilicia (Latakia, Kassab). ${ }^{1}$

\footnotetext{
${ }^{1}$ Shown in italic are sites of carvings on flat stones, as well as antique and medieval remains of rock art tradition, in bold - huge, deeply carved signs. Images in Loriberd, Buth, Aryutzablur, Antalya and Kortun are cerr paintings.
} 


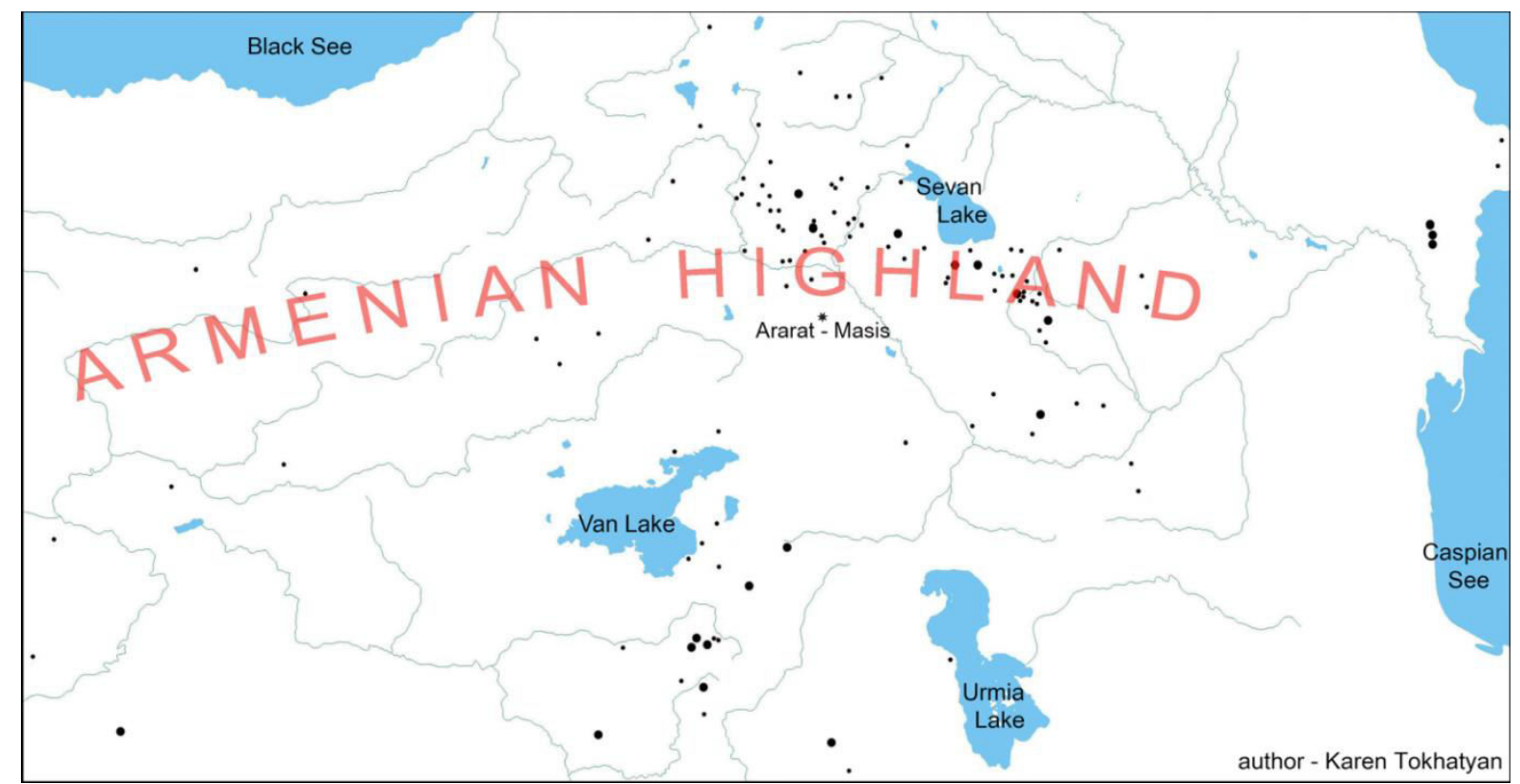

Rock-art sites of the Armenian Highland

To the west of Great Armenia ancient rock carvings are known in the vicinity of Attalea (Antalya), in the mountains of the Cilician Taurus (Kortun cave), in Nigde, in SE - in Iran (Kangavar, Hamadan, Lor, Mirmirlas, Teymere, Golpaegan). To NE there are early medieval drawings - in Dagestan (Buynaksk, Kapchugay, Chirkata), in Georgia (Mghvimevi - near Chiaturi), in Abkhazia (caves Agtsa and Guarap), and in the slopes of Caucasus Mountains (Gundelen, Urushten).

Types and technique. The vast majority of ancient petroglyphs of Armenia are carved on unhewn surfaces of hard volcanic stones - boulders and splitted outcrops. Dimensions of drawings vary from $10 \mathrm{~cm}$ to $4 \mathrm{~m}$, with depth of 1-20 mm and furrow width of 5-30 mm. There are both stand-alone and grouped engravings.

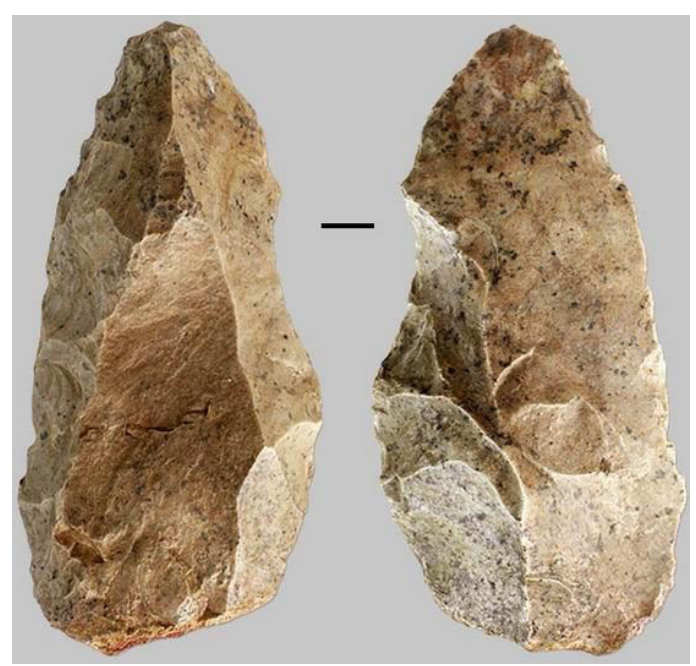


The petroglyphs are carved out on dark- shiny and sunburned surfaces of andesite- basalt rocks by stone-cutters, later substituted by metal ones. The rocks are extremely hard. During millenia the influence of oxidation and erosion processes made on surfaces of stones a thin, shiny sunburned layer.

Content. Almost all spheres of human life are reflected in Rock Art. They convey valuable information about the environment, life and traditions, crafts and skills, arts and knowledge of ancient people, about their spiritual world - mythology and world perceptions. Rich subject of Armenian Rock Art is divided into 30 thematic groups: static elements of environment (mountain, volcano, river, lake, spring), natural phenomena (lightning, clouds, rain, rainbow), the heavenly luminaries (Sun, Moon, star, stellar group, constellation), Earth, rare celestial phenomena (eclipse, meteor, comet).

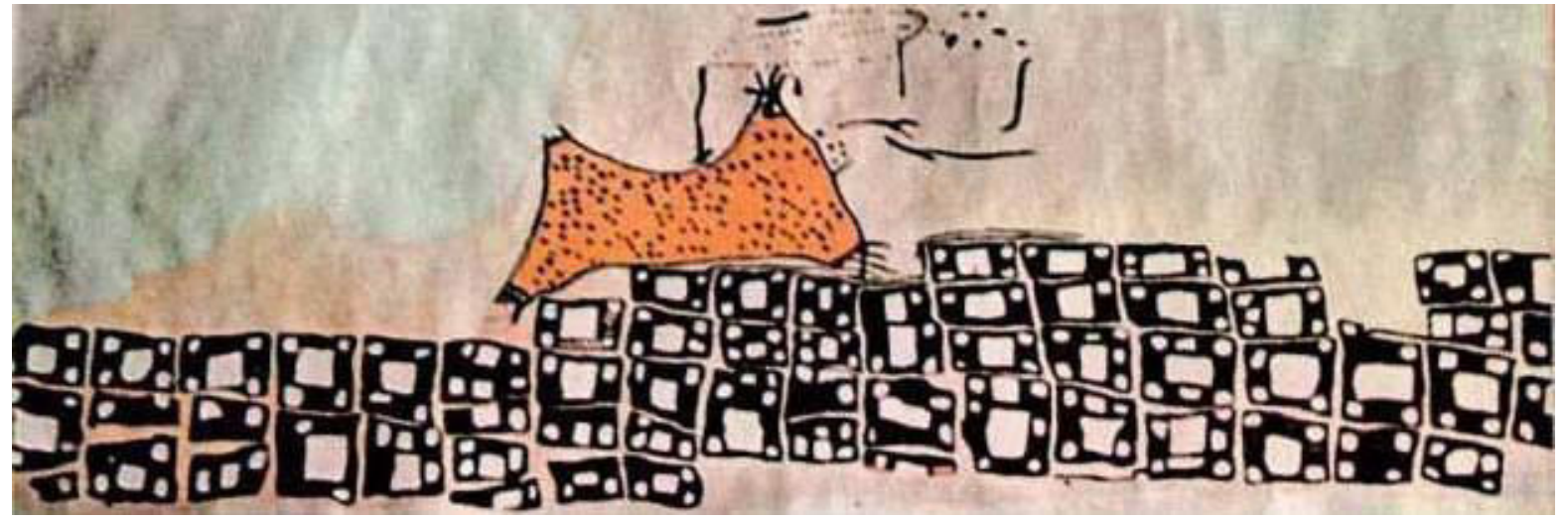

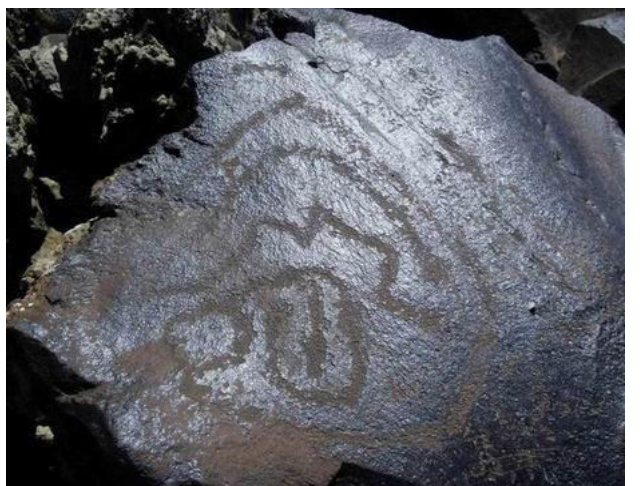

Araler, Hatis, and Aragats mountains.

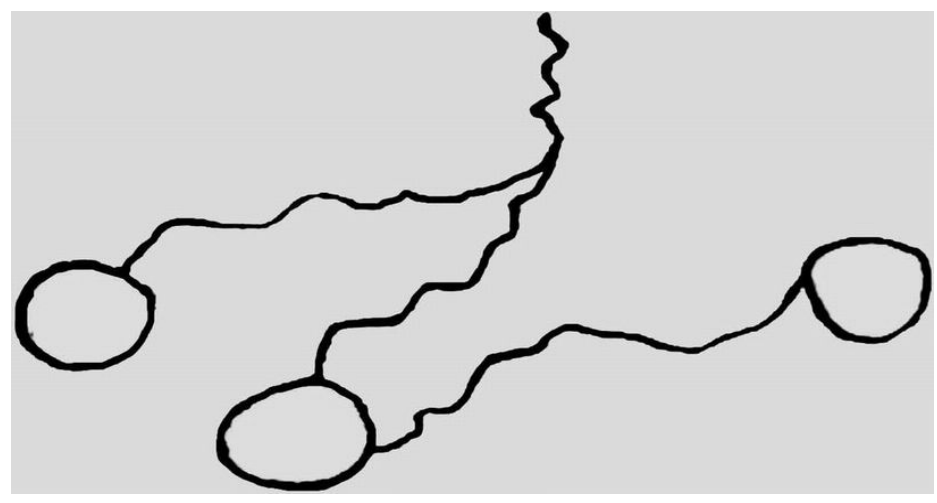

Volcano. Lakes and rivers in Navasar 

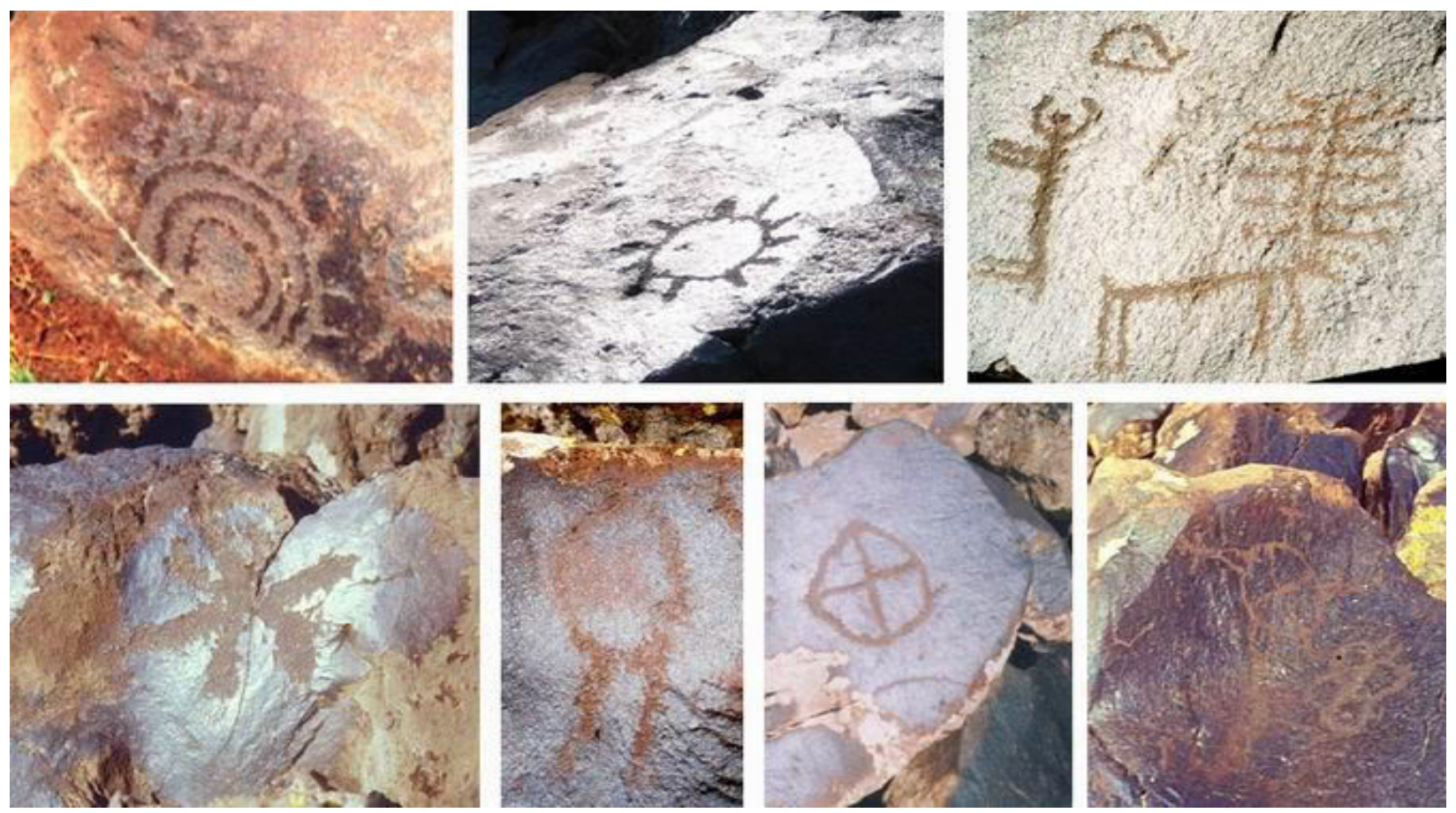

Sun, Moon, a star, a comet, Globe

The majority of images are those of flora and fauna (bezoar, mouflon, deer, gazelle, horse, bull, tour, bison, wild boar, bear, leopard, cheetah, lion, wolf, dog, fox, snake, birds),
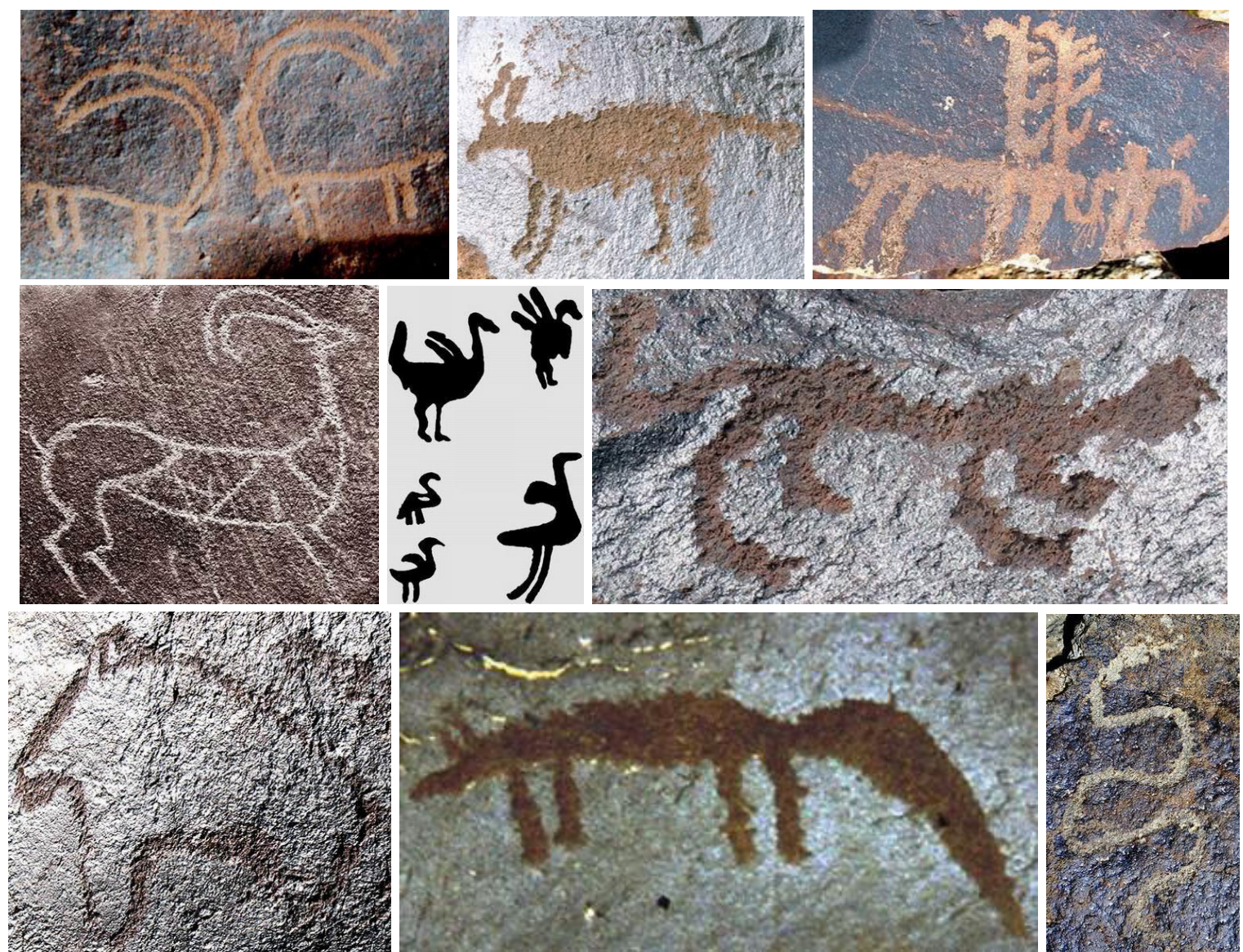

Goats, bull, man with deer, gazelle, birds, leopard, bear, fox, snake 


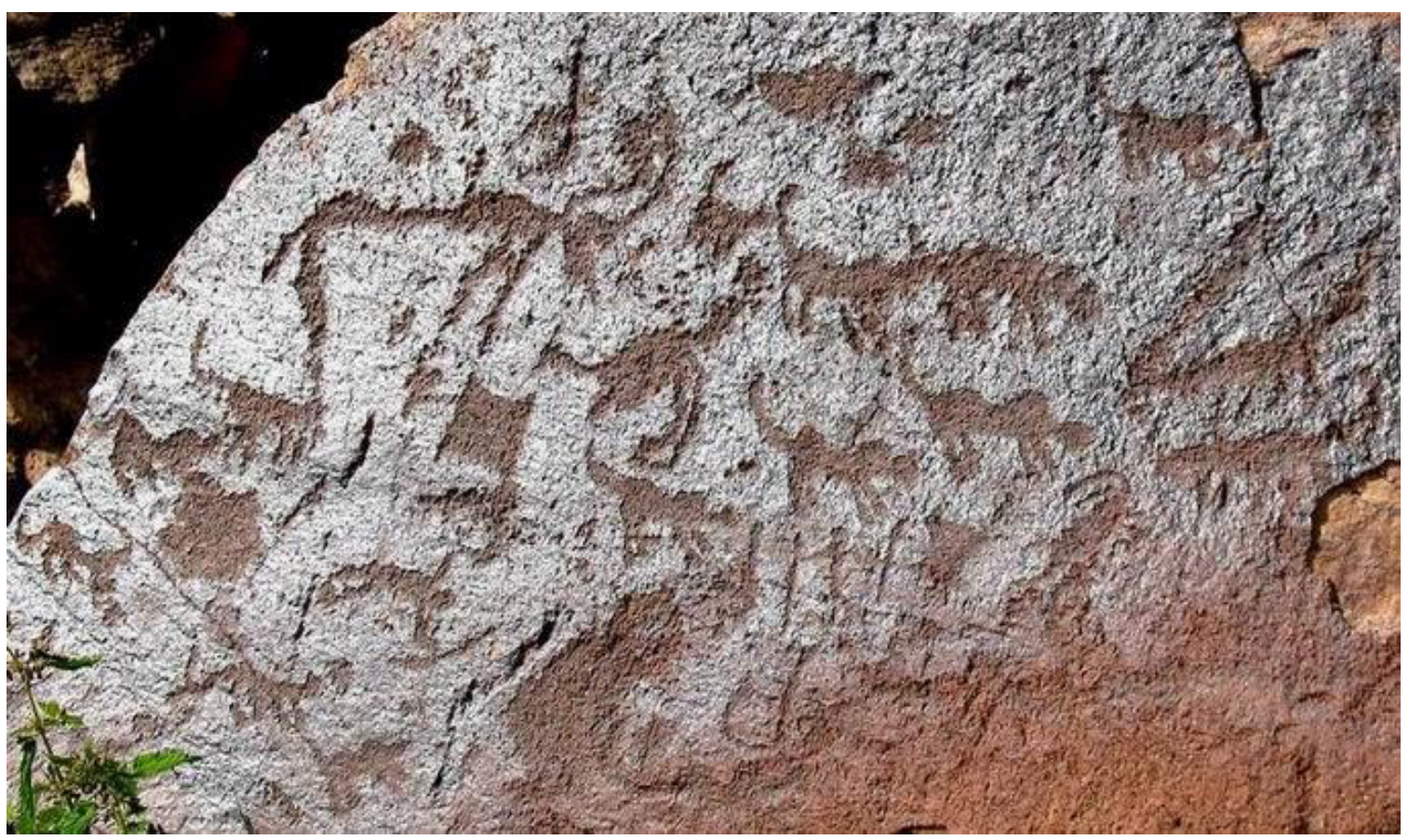

A group of wild animals in Geghama mountains as well as mythical creatures, vishaps /dragon/
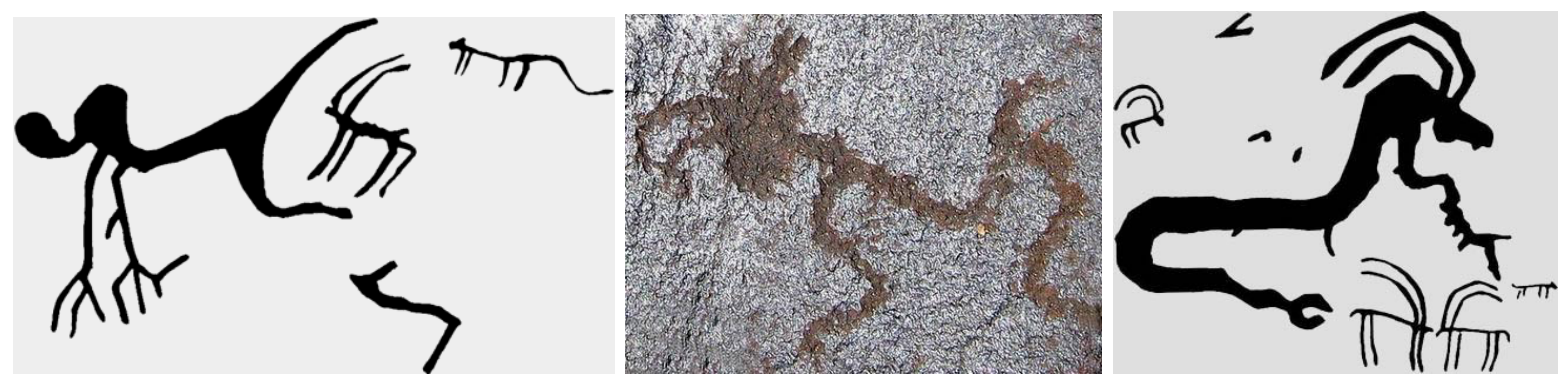

Vishaps /dragons/

Most commonly life and activities of man are reflected (hunting, fighting, animal husbandry, domestication, land cultivating, plowing),
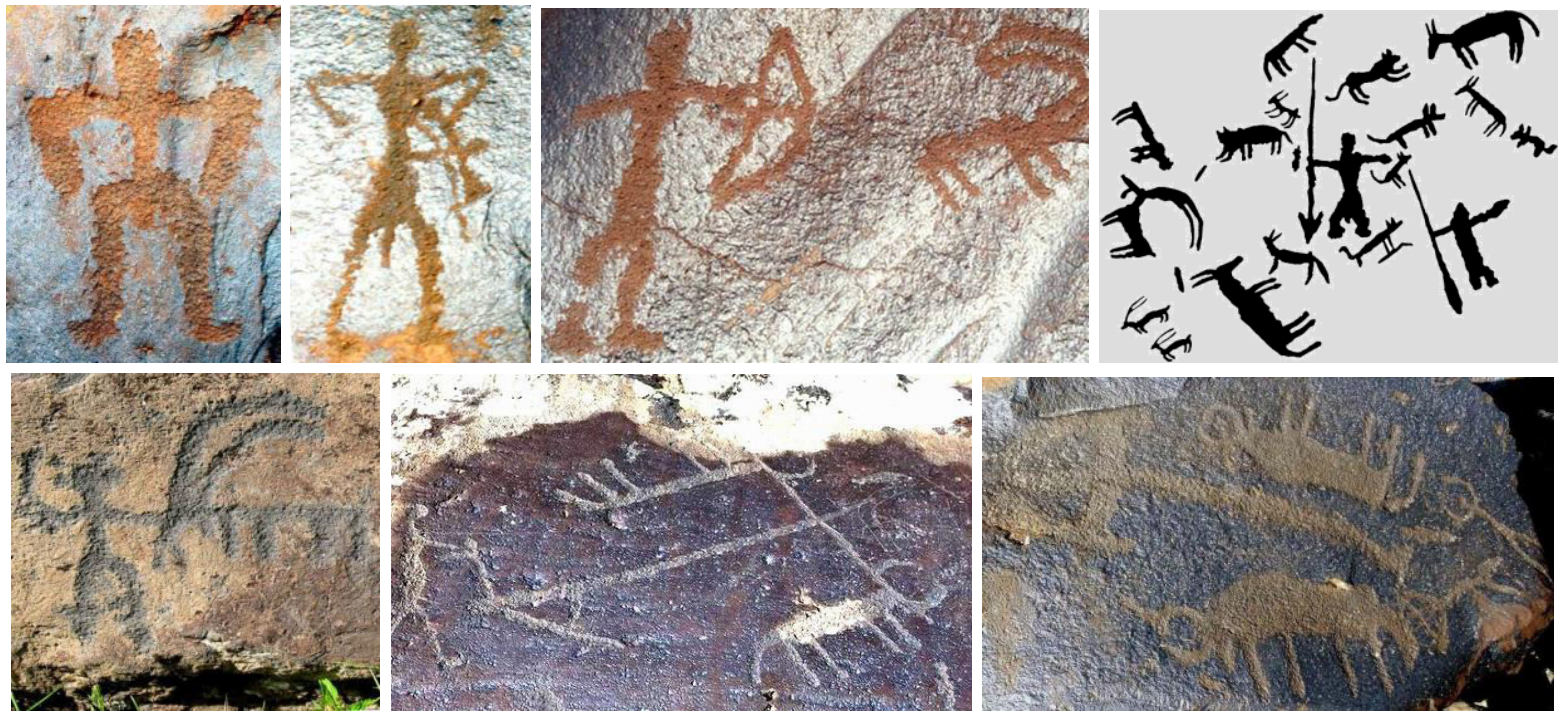
ceremonial life and rituals (the worship of motherhood, ancestors, deities, heroes, twins, good spirits, fertility, and time).
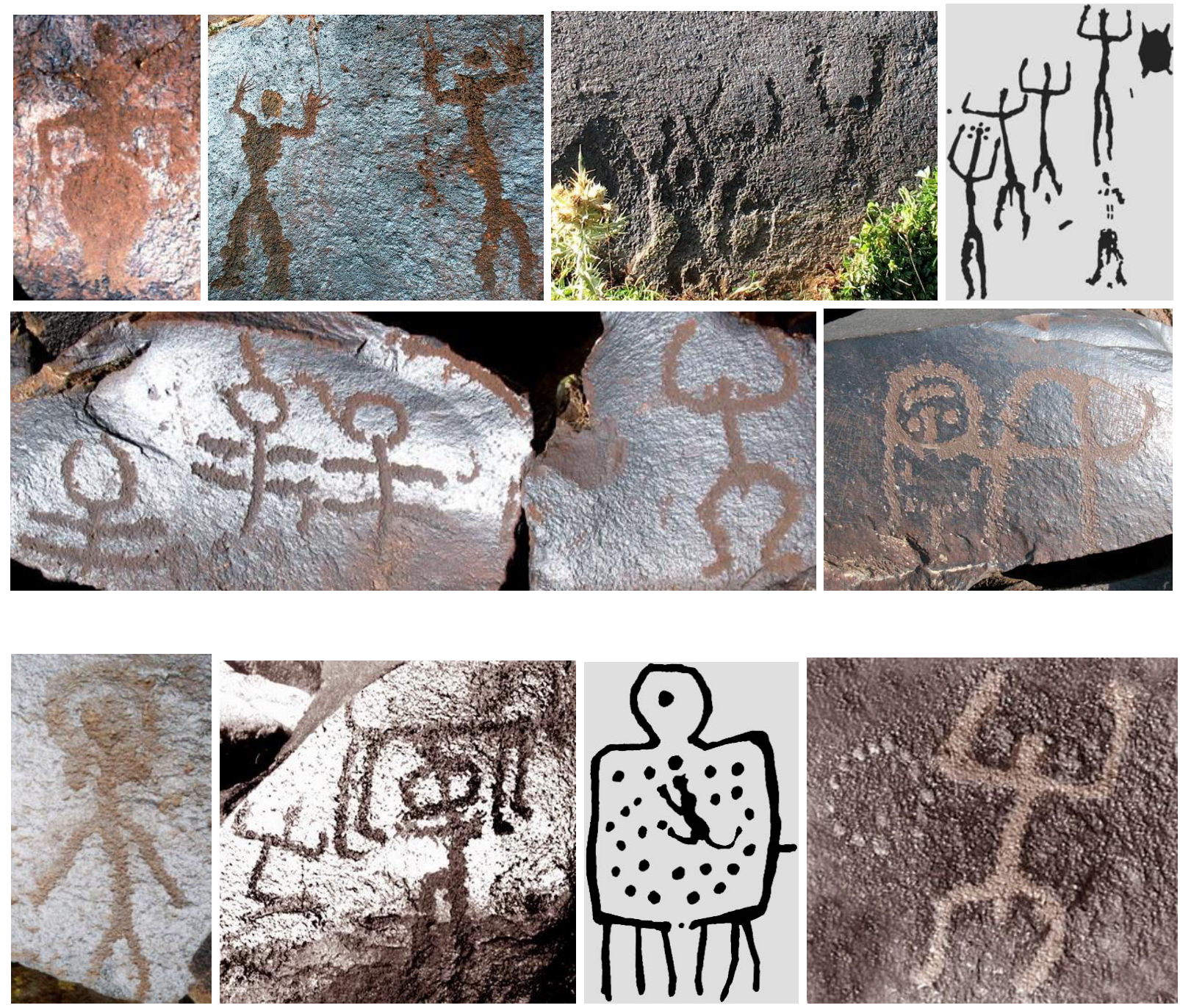

Many images depict men in scenes of sports and competing, playing games and dancing, weapons,
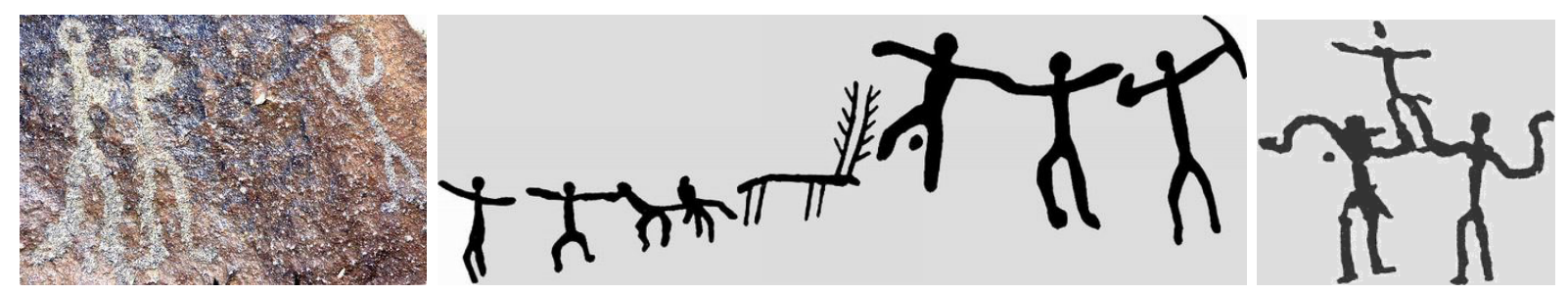

tools and accessories (bow and arrow quiver, shield, spear, mace, baton, hook, lasso, a plow, a network, a ladder), vehicles and transportation means (cart, chariot, boat, skiing, sleigh). 

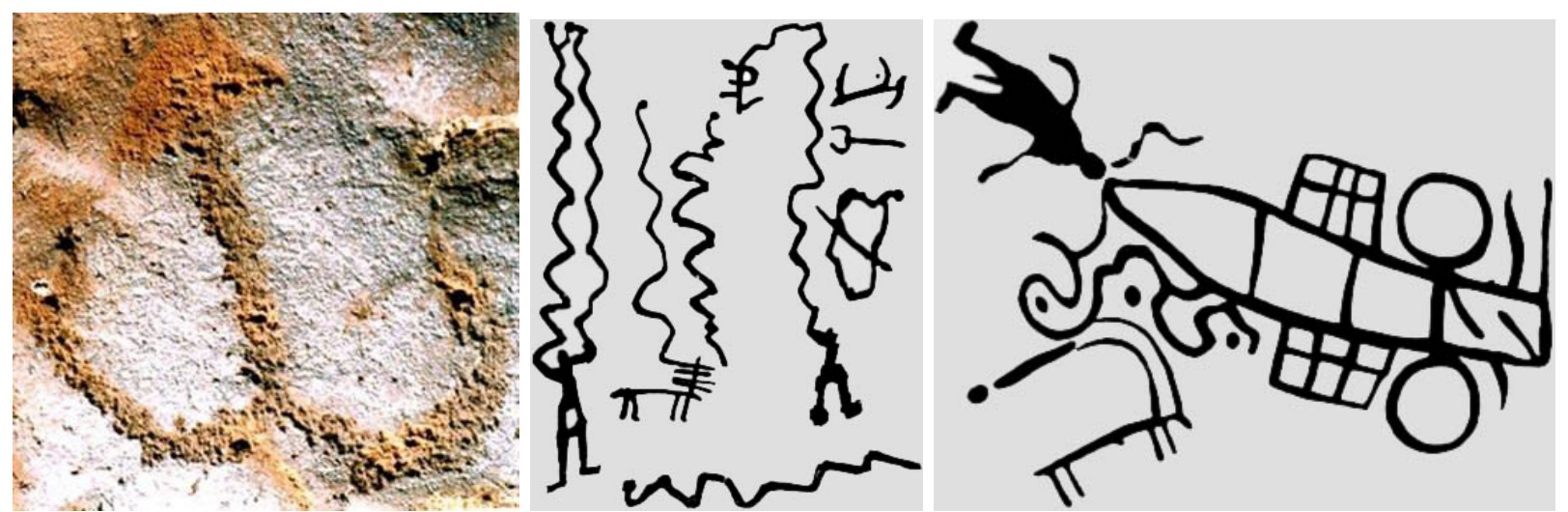

Ancient scientific thought is expressed in sky maps, calendars, compasses, and in the plans of surroundings and irrigation systems,

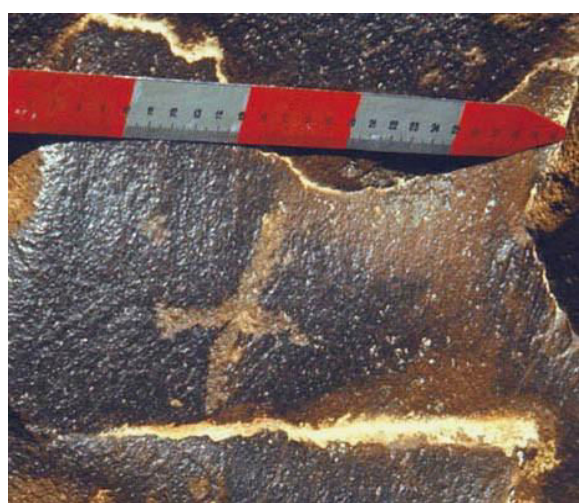

A compasse

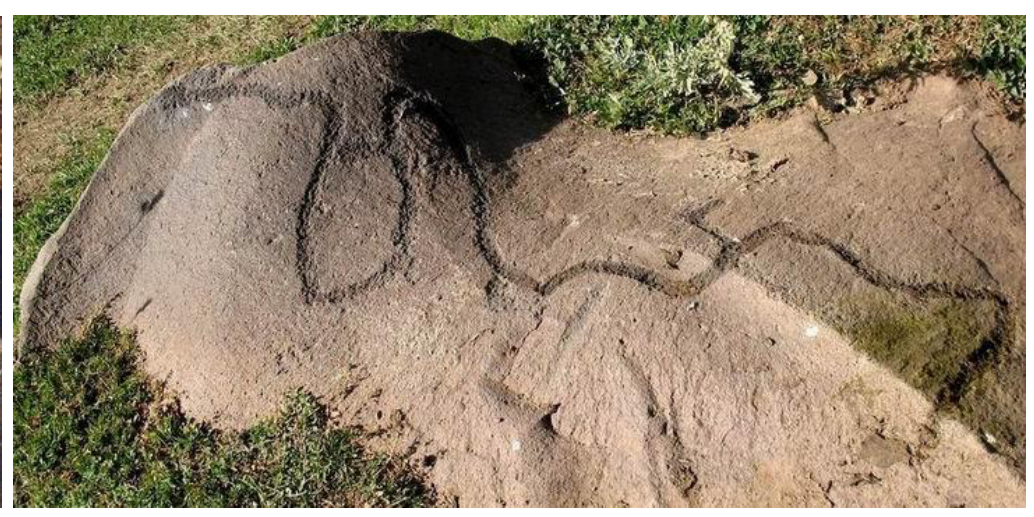

A plan of irrigation system

in the drawings of buildings (settlement, shelter).

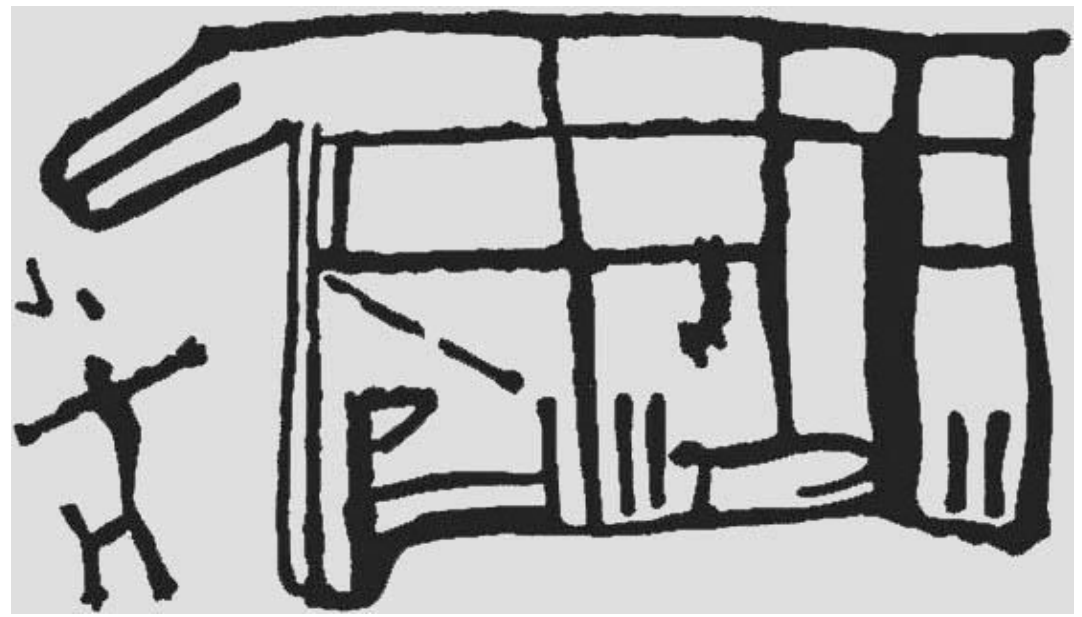

Some rock-carvings had an applied astronomical significance: solar (30/31-day, 12-month, 354/365-day annual) and 7, 14 and 28/29-day lunar calendars, sunrise/sunset and Earth poles' markers. 

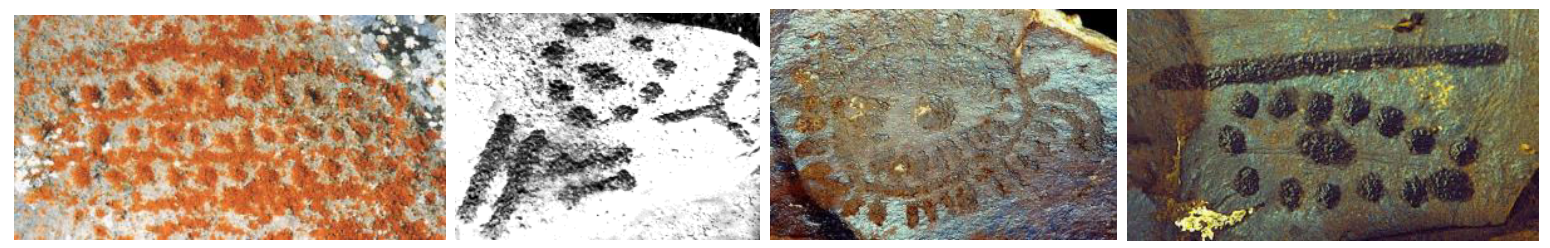

There is a variety of patterns, symbols, including signs, similar to the letters of the Armenian and other ancient alphabets.
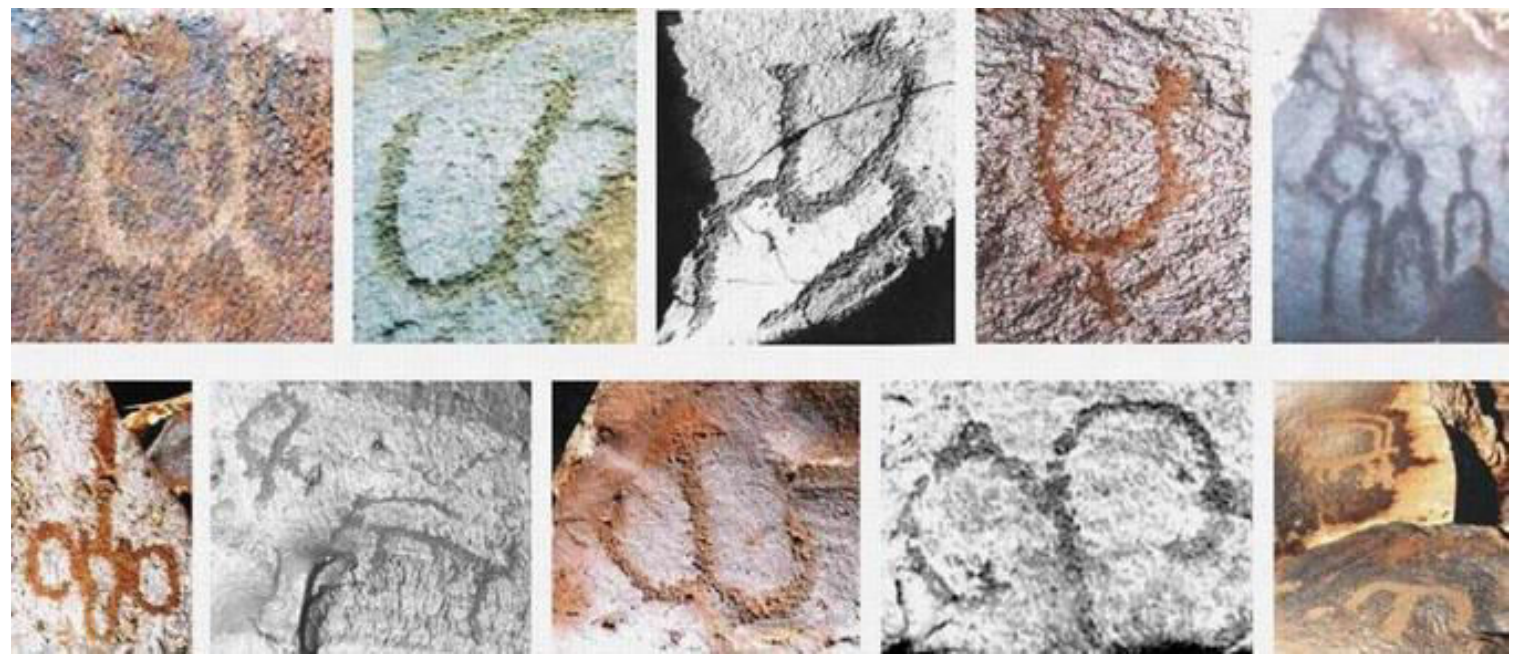

Some signs almost in the same shape and meaning were used up to medieval times in Armenian ideogram system. One can see many sketches, hyperbolic, schematic, precise and unfinished images, as well as examples of complex projection and perspective, palimpsest and portrait.
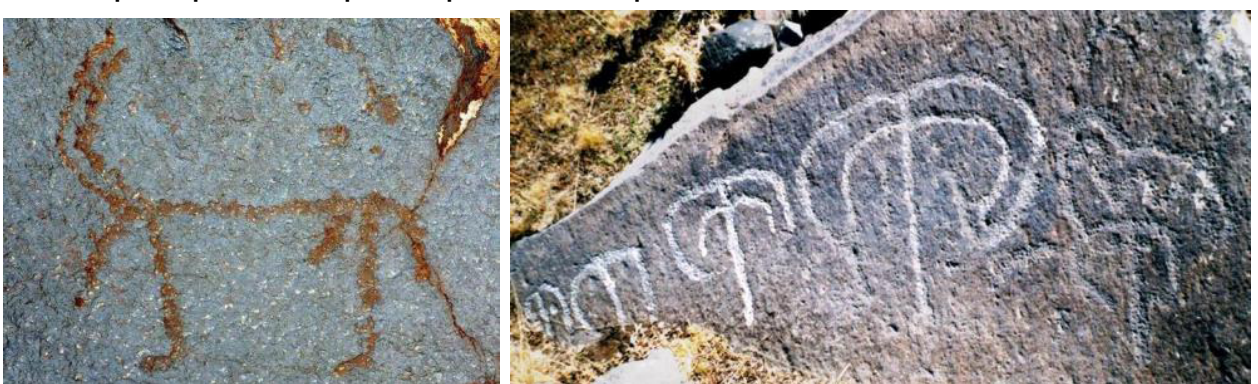

Most of those figures are impressive in their realism and expressiveness, dynamics and tension of pose and action.
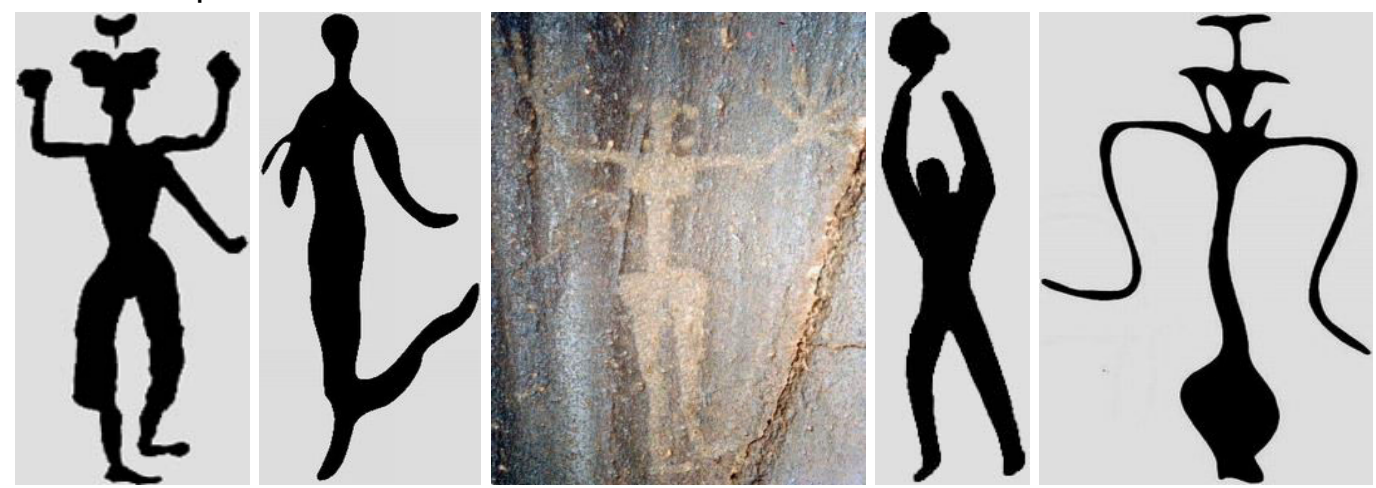
Some of the above mentioned thematic groups - star charts, letterlike signs, dragons, calendars are either absent in other parts of the world or rarely met. Armenian petroglyphs differ from the others by one more very important and significant aspect: violent scenes are completely absent among them, apparently as a result of the taboo on such images.

Research methodology. This unique type of informatic source is reliable only in the case of considering the petroglyphs together, study them comprehensively and systematically, i.e. to find all the pictures, fix them by technical means (photography, video, copying, aerial photography, accurate GPS mapping, and 3D recording).

Rock Art must be reviewed in an historical-archaeological culture context. Attaining this aim is possible only through a classification, which takes into account the influence of almost all known natural and human factors, beginning from the formation of rock-fragments through to engraving and up to our days. Classification can be done through nearly 350 parameters and properties, grouped in seven categories: monument, stone, which carries picture, engraved surface, drawing, furrows and lines, surroundings of monument, groupness.

Thanks to such a theoretical and practical classification it will be possible to reveal the meaning, role and function of each rock-carving, each group of rock-images, and by determining Rock-art Tradition and Rock-art Culture, finally of Rock-art in general. The classification of available material is a prerequisite for the development of this branch of science.

Dating. Commonly scientists have used comparative biological, geological, archaeological methods and complex studies for age determination in general. In case of engraved images their precise dating is extremely difficult, since it is impossible to apply traditional well-known methods of natural sciences (radiocarbon dating, dendrochronology, pigment, spectral, palaeomagnetic, pollen, ultrasonic, collagen analyses, etc.). The achievements of contemporary Rock-art investigations have not managed to develop a precise dating of rockcarving yet.

Consequently, the only methods are relative-comparatives, based on the analysis of content, style and technique of drawing with other archaeological monuments: nearby structures (settlement, burial place) and artifacts found nearby (tools, weapons, ornaments, pattern, and painting on ceramics). These historical-cultural comparisons give too approximate evaluations and indicate the 
age with accuracy up to 1-2 thousand years, and then indirectly.

Thus, it is admitted that the era of our ancestors' rock-carving activity has lasted from VII up to the I millennium BC.

For solving the problem of dating the complex materiological, traceological, ethnographical, cosmological studies and, in general, a variety of combined approaches are important. For absolute dating of carved images most reliable are the astronomical methods.

To make it easier for orientation in the dark sky, about 5000 years ago man folded from the bright stars sustainable and memorable images - constellations. The description of constellations comes from the Alexandrian poet Arattes (315240 BC), written upon Eudoxes' work (408-355 BC) $)^{22}$. Arattes speaks about deep and unknown antiquity of the origins of constellations.

In 1910, the historian of astronomy W. Olcott, summing up the assumptions of the archaeologist Ed. Maunder, astronomers K. Swartz, C. Flammarion and A. Berry, came to the conclusion that the Zodiac constellations were formed and got their names on the latitudes of $36-42^{\circ}$, between the Caspian and Aegean Seas, by people lived in the Euphrates valley and in the vicinity of Ararat Mountain, in 3028 ce. $B C^{33}$.

These conclusions scientists have made theoretically, by examining astrogeographical (with which latitude and in what period of the past were seen those constellations), zoo-geographical (on areas of residence of the animal represented in the Zodiac) and general archaeological data. They could even not know about the cosmological perceptions and their material realization in form of artifacts (astronomical constructions, observatories, belt-calendars, shield-calendars, and especially the astronomical rock-drawings) in Armenia.

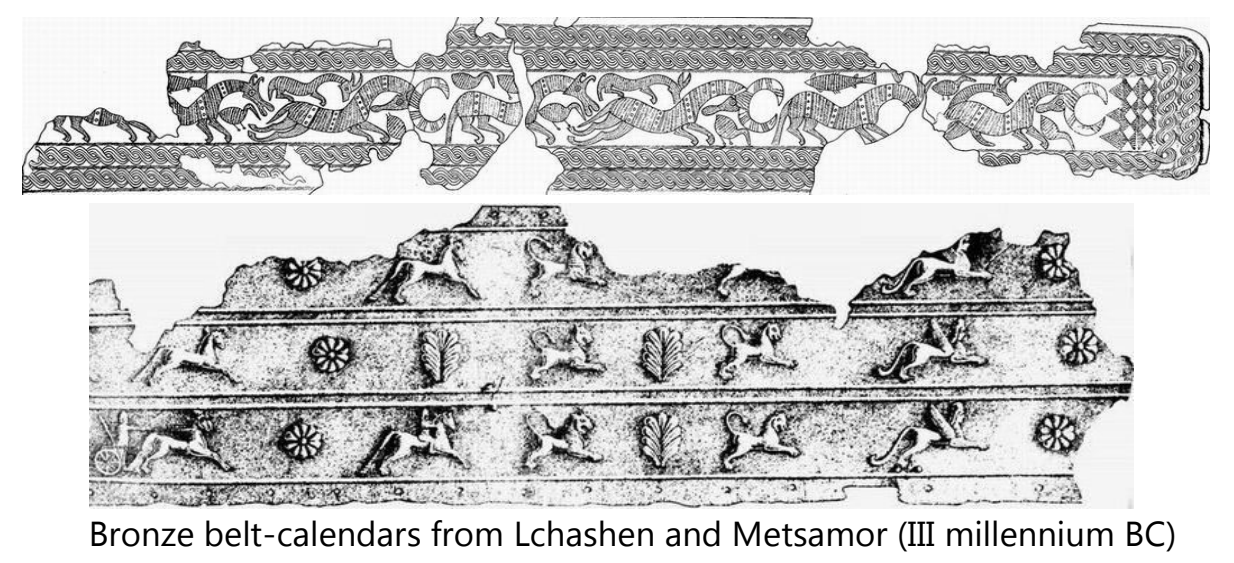

\footnotetext{
${ }^{2}$ Житомирский С. В., Итальянская Е.Г, Астрономия. Энциклопедия, 2013, с. 77.

${ }^{3}$ Mounder Ed., Astronomy, Without a Telescope, London \& New York, 1904; Swartz K., 1809, Flammarion C., Histoire du ciel, Paris, 1873; Flammarion C., Astronomie populaire, Paris, 1880; Berry A., A Short History of Astronomy, London, 1898, p. 3, 12-14; Olcott W., Star Lore of All Ages, New York, 1911, pp. 7-8.
} 
The European authors' analytical conclusions are corroborated by material discovered during the last 35 years - engraved star-groups, calendars, maps, astronomical centers (Metsamor, Vardenyats, Sevsar, Zoratsqar, Portablur, etc.), findings in the archaeological sites (Astghaberd, Koghes, Agarak, etc.). It is obvious that those who first divided the sky into constellations were prehistoric inhabitants of the Armenian Highland.
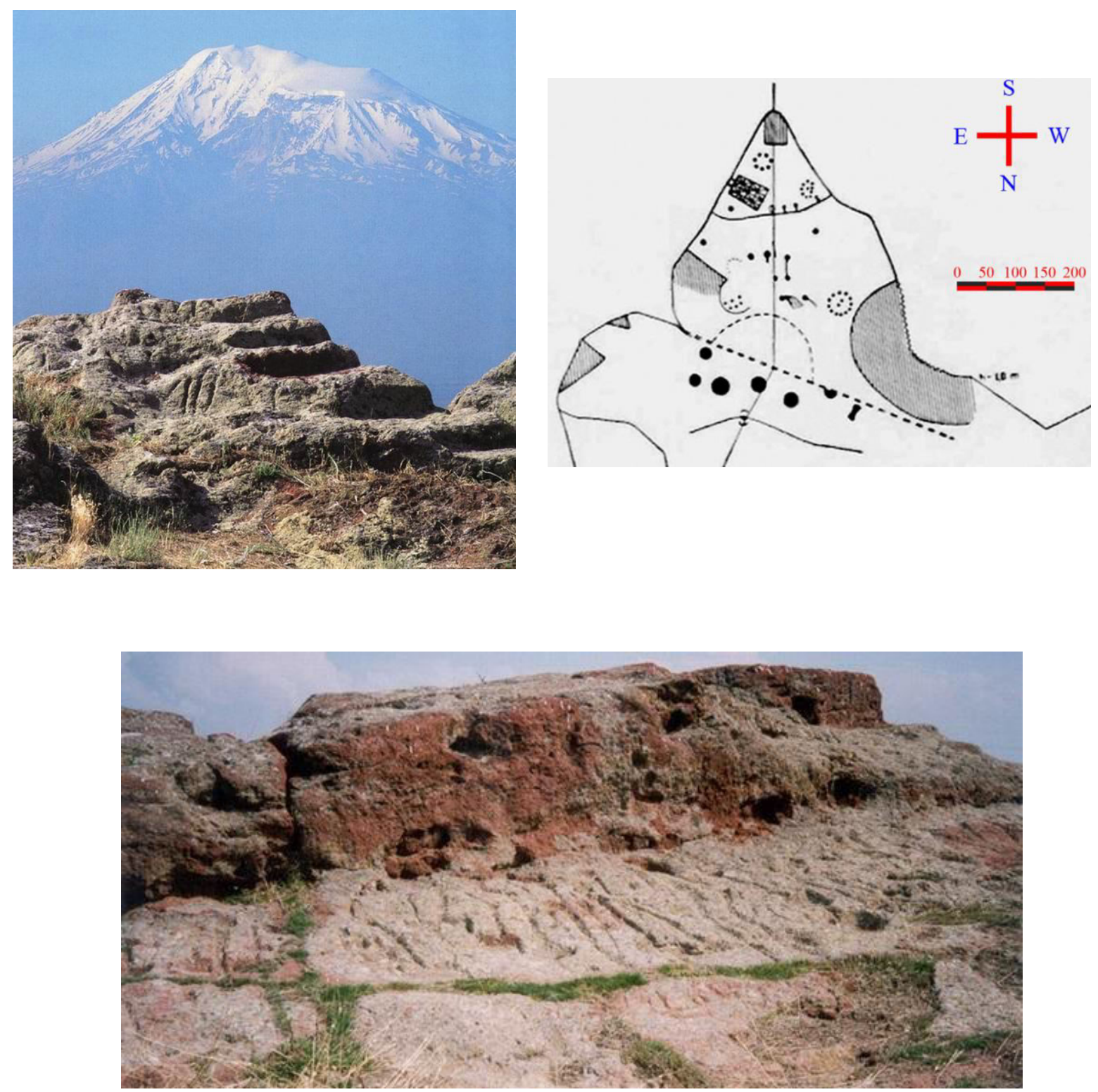

Metsamor (III millennium BC) 


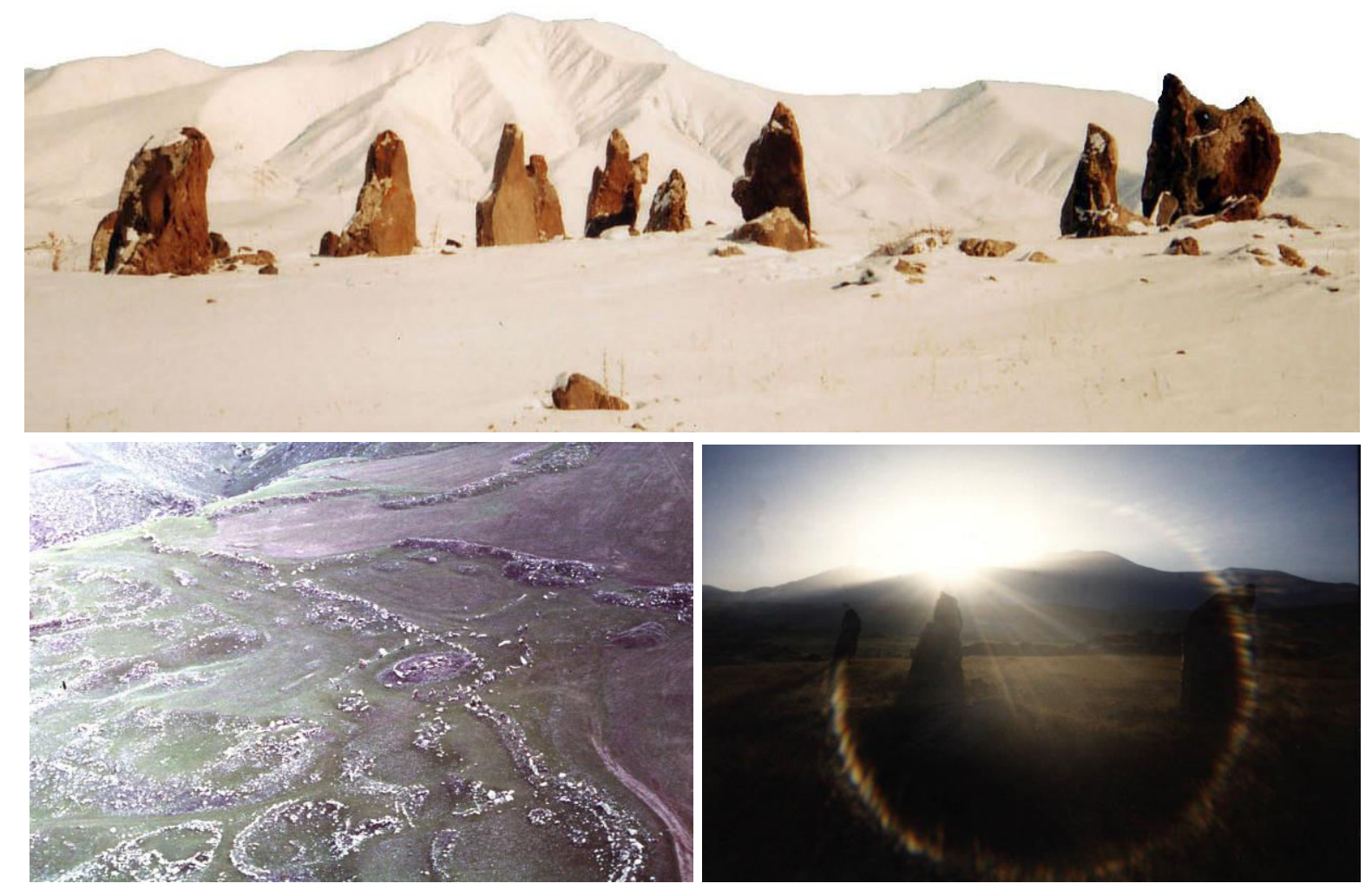

Zoratsqar in Syunik (VI-V millennia BC)
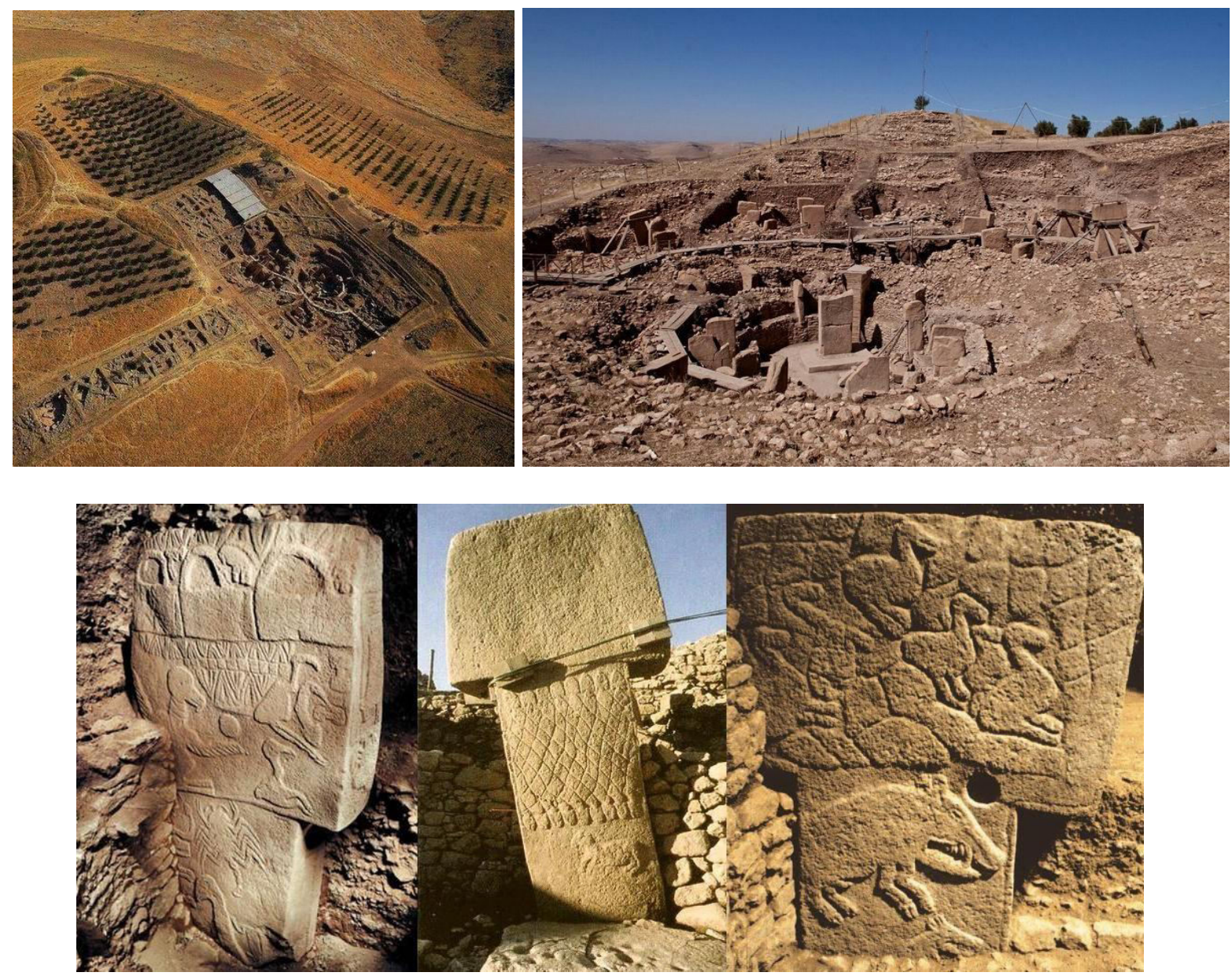

Portablur (Umbilical hill) (X-VIII millennia BC) 
About Armenia as a cradle of ancient astronomy, witness also some new archaeological discoveries.

In 1964, architect S. Petrosyan found at the top of the Vardenyats pass (2410 $\mathrm{m})$, a dozen large stone slabs engraved with rings. Being on the edge of the ancient caravan route (branch of the Silk Road), protected by cyclopean fortresses and connecting Sevan Lake Basin and Arpa River valley, they very likely have had ritual and orientation significance serving as a guide. In 1969, the Armenian historian of astronomy B. Tumanyan identified those images with Zodiac constellations of Leo, Sagittarius and Scorpio. The stars are represented by dots and circles, accordingly to their brightness ${ }^{4}$.
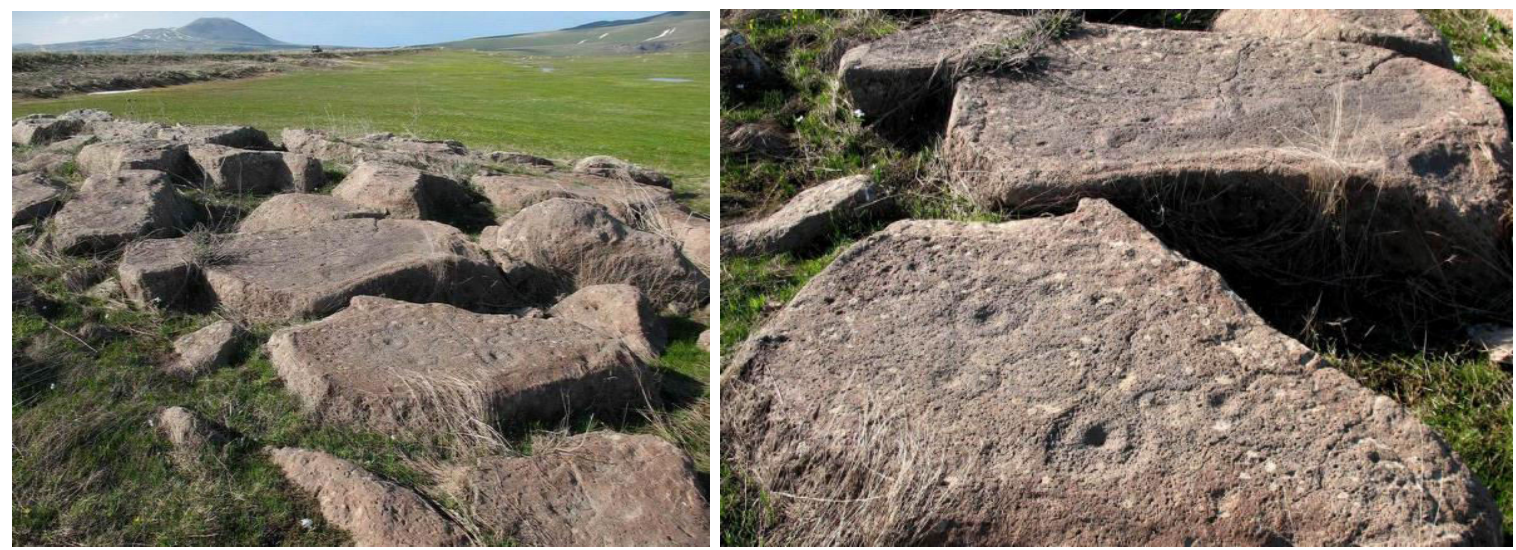

In 1995 was developed an astronomical method of their absolute dating. ${ }^{5}$ It is a common knowledge from astronomy that all the stars have their proper movements. The movements are too slow and the derivations too small in order to be noticed by man during a lifetime, but perceptible enough to shift noticeably during millennia. Thus, engraved stellar configurations, though different from their current-day arrangement, remain recognizable. The method is based on the comparison of the engraved configuration of a certain constellation with its present view, and the assumption that the image was made with enough precision, i.e. was similar to the shape of that constellation at the moment of engraving. By reconstructing the shape and position of the constellation in the past and comparing them with the view of the rock-carving, the precise time it was carved can be ascertained, i.e. the absolute age. Thus, the age of the above mentioned rock-carving with images of Zodiac constellations of Leo, Sagittarius and Scorpio is determined as 27-25 centuries BC.

In 1965, on the North slope of mt. Sevsar of Vardenis Ridge at a distance of 9

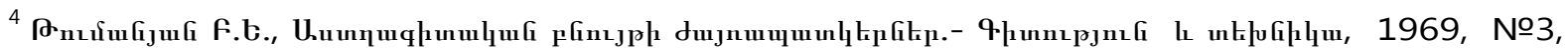
19 7-9:

${ }^{5}$ Tokhatyan K.S., The Chronology of Rock-Carvings with Cosmological Meaning from the Geghamian Range.Theses of Reports $2^{\text {nd }}$ International Congress of Rupestrian Archaeology, Valcamonica, Italy, 1997.
} 
$\mathrm{km}$ from these astronomical maps, at an altitude of $2650 \mathrm{~m} \mathrm{~S}$. Petrosyan found a great complex of carvings with astronomical content - 20 pictured rock-pieces within an area of 50 by $20 \mathrm{~m}$.

B. Tumanyan interpreted the image on the huge main stone as a result of observations of a rare celestial phenomenon - a large meteor. He concluded that the big round image represents a bright bolide and the adjoining pictures are constellations and the Milky Way branche. So, this is a stellar map, which shows a sector of the Sky from where the bolide descended ${ }^{6}$.
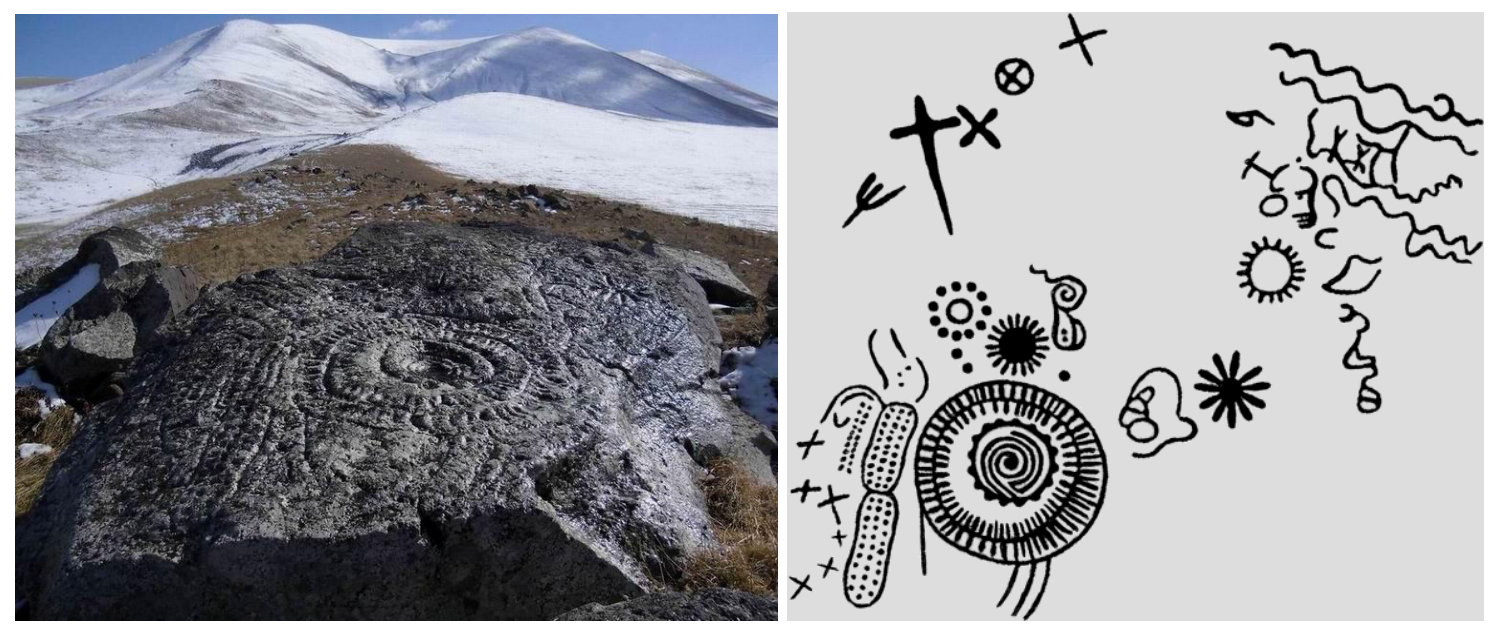

In 2000 the author expressed an opinion that Sevsar could give opportunity for its dating. Supposing that the three lines on the right part of the image show the direction of the bolide's flight, he pointed to notice the 30-meter diameter and $5 \mathrm{~m}$ deep crater at the foothill of $\mathrm{mt}$. Azhdahak $(3597 \mathrm{~m})$ and proved that it was the result of the meteorite's falling.
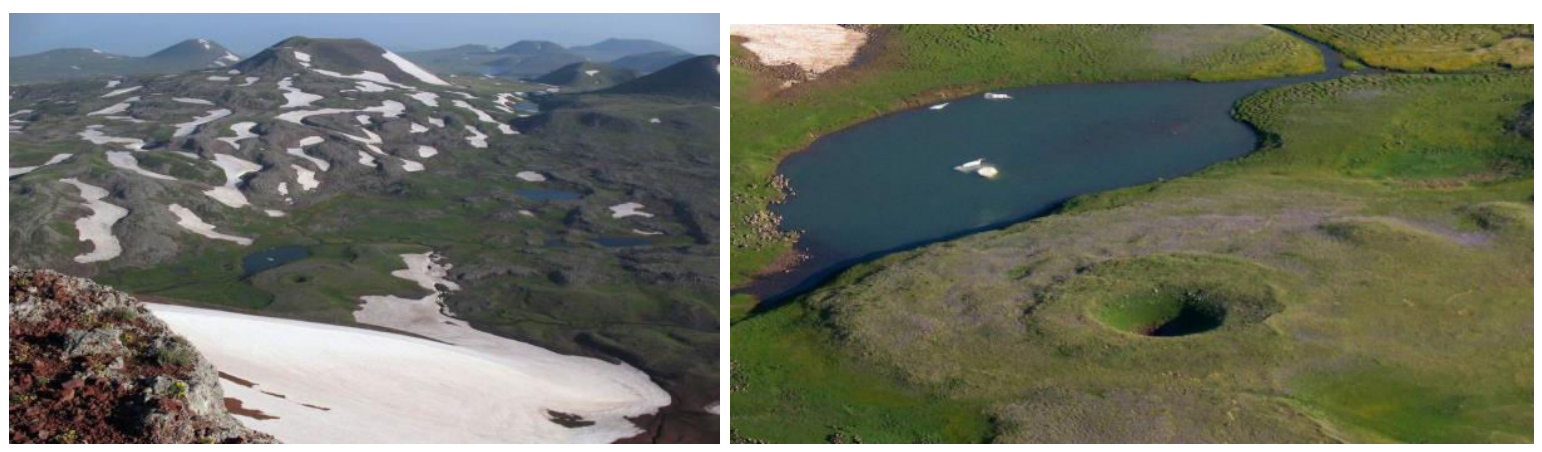

When the meteorite (or its fragments) and the traces of its impact are found in the crater, the time of the collision (formation of crater) may be scientifically defined. Respectively, this will afford the opportunity to more precisely define the

\footnotetext{
${ }^{6}$ Туманян Б., Астрономические наскальные рисунки Армении.- 1963, №3, с. 107-108.
} 
absolute age of the Sevsar astronomical complex, dating back supposedly to II-I millennia $B C$. These two astronomical methods make possible the absolute dating of about 35 rock-images.

During the following decades ancient observatories were discovered dated IIIII millennia BC: Metsamor ${ }^{7}$, Zoratsqar ${ }^{8}$, Koghes, Agarak, Portablur. In Basen field, at village Tandzut there is a huge structure called Sharvan Qarer. On the north shore of Van Lake, at village Lezq huge rows of stones are preserved, with possible calendaric meaning. Also the bronze calendars of kings and priests of the Van Kingdom are preserved.

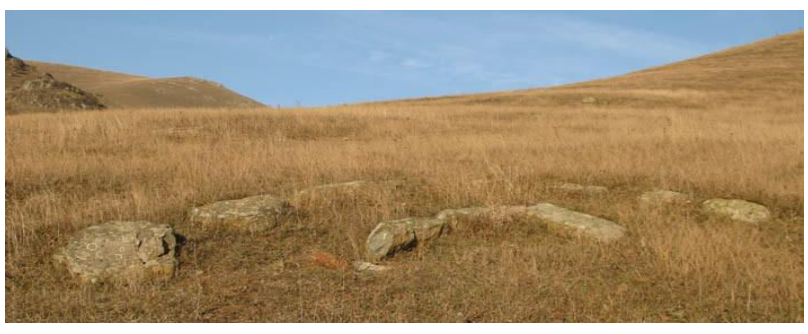

Koghes in Lori

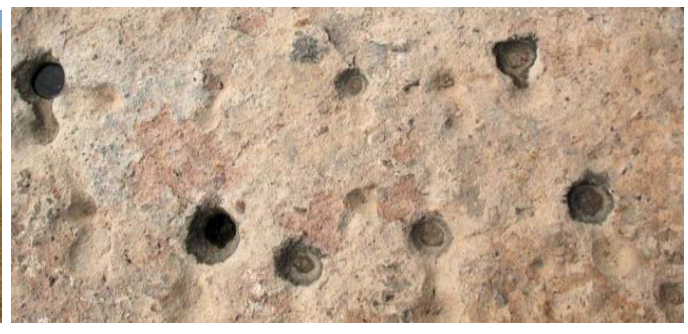

Agarak in Aragatsotn

Past references to Rock Art. Father of Armenian historiography Movses Khorenatsi (V c.) knew about rock images in Armenia. He retained in the form of a mythical narrative two striking evidences of rock-art. In connection with the rockcarvings and iconography by epic hero and demiurge Torq Angegh the historian writes: They sang that he took in his fist hard stones, ... crunch them into large and small pieces at will, polish them with his nails, and form them into tablet shapes, and likewise with his nails inscribe eagles and other such designs on them. ${ }^{9}$ And in connection with creation of the alphabet by Mesrop Mashtots (V c.), the historian writes: And he sees no sleep the night vision and reality, but in his heart beating opened eyes of the soul right hand writing on the stone $U, E, F, F, \Omega, F$. Stone just like snow, retains traces of faces. ${ }^{10}$

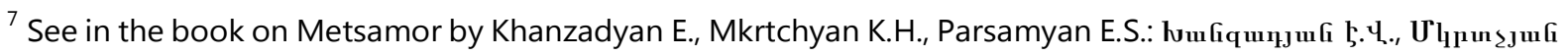

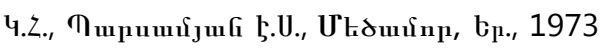

8 Парсамян Э.С., О возможном астрономическом назначении коолец Ангелакота.- Сообщения Бюраканской обсерватории, 1985, 57, с. 101-103, Геруни П.М., Доисторическая каменная обсерватория Карахундж-Карениш.- Доклады АН, 1998, 4, с. 307-328

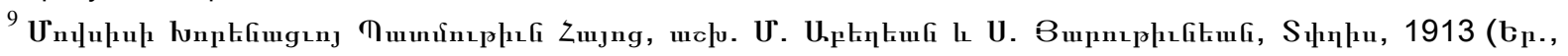
1991), F qhpf, C, $t_{2} 115$ :

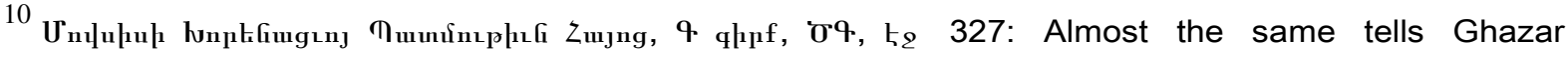
Parpetsi

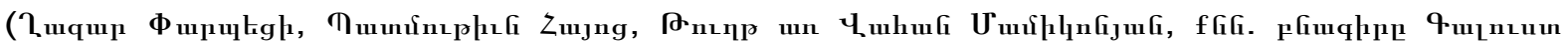

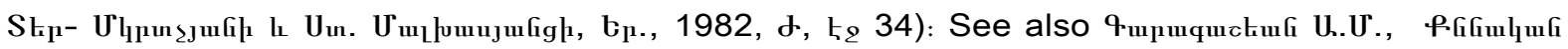

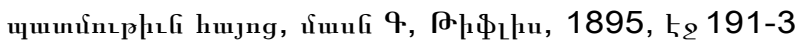




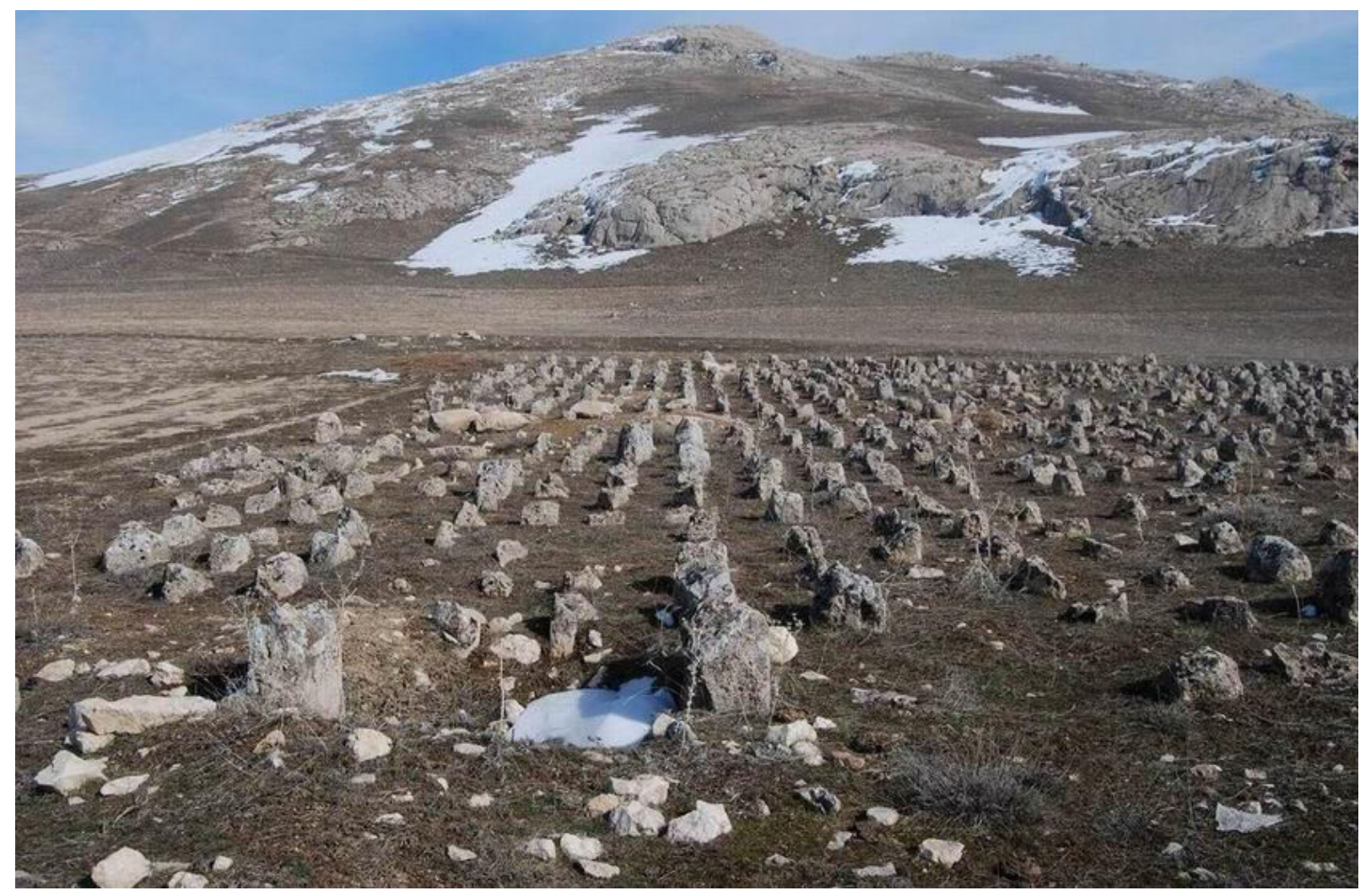

Lezq (II millennium BC)

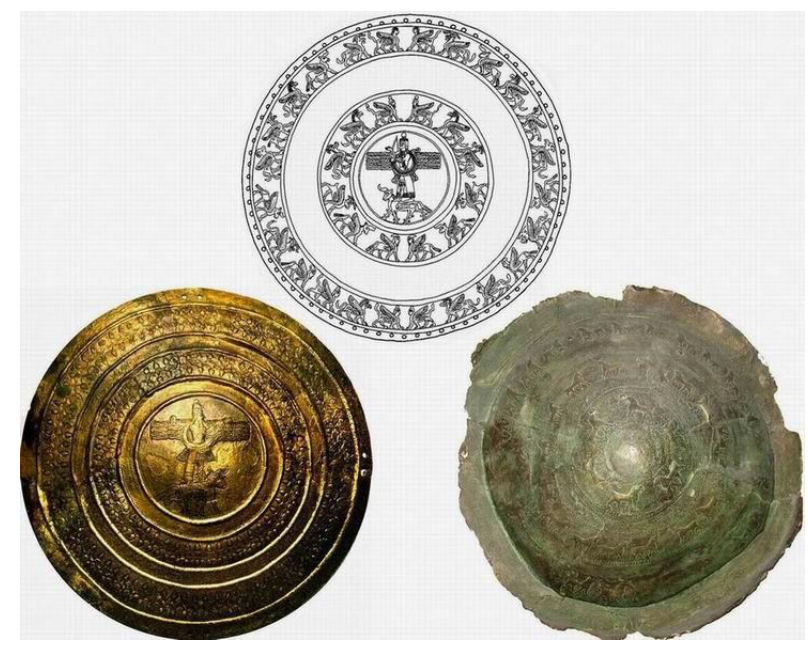

Bronze shields of the kings of the Van Kingdom

More direct is Armenian philosopher, mathematician and astronomer Anania Shirakatsi's information: the receptors of our ancestors were more sensitive than ours, due to which they could notice not only the movement of the Sun but also inscribe, i.e. carve and recognize the movements of all the other luminaries and stars. ${ }^{11}$

This fragment saved by the coryphaeus of Armenian science, is the earliest in

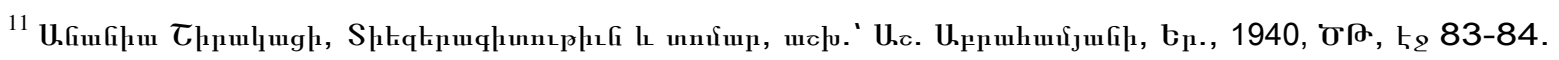


the world written evidence about the existence and antiquity of rock-drawings, because the word "carve" in Armenian also means inscript, make sculpture.

It is very important that Shirakatsi mentions this sequence of studying phases: carve and recognize, i.e. first the noticed positions of heavenly bodies had to be recorded, fixed (collecting and accumulating the knowledge), and only after that they had to be researched and recognized (understanding the rules of luminaries' movements). It must be taken into account that astronomical processes are very slow, and man cannot notice and remember the considerable displacements of stars during his lifetime. Therefore, periodical recordings were needed: every day, every week, or every year and so on.

Thus, Shirakatsi knew that in past times the observational data on the movement of the heavenly luminaries used to be recorded on stones (as it was the best material to fix and preserve the information). Moreover, his information is witness to the existence of astronomical rock-carvings. A striking example of this is the petroglyph in Geghama mountains, at the foot of mt. Astghaberd, at an altitude of $2920 \mathrm{~m}$. The rock is situated on the top of the dominating hill, it has $1 \mathrm{~m}$ length and is firmly fixed among the other stones. The image looks to the North, so that the observer sees both drawing and the southern part of the sky, the most convenient and effective point for astronomical observations.

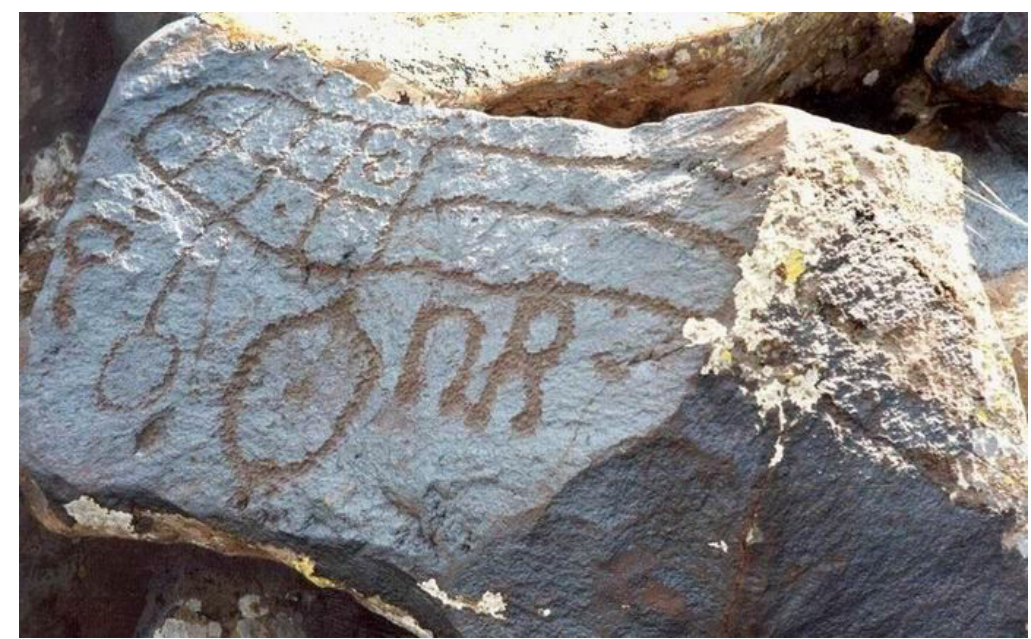

The author suggested it as a table of astronomical records, which shows the visibility of two certain celestial bodies being observed, perhaps planets, stars or constellations. Such an imaging makes it possible to compare the relative movements of luminaries.

Our ancient ancestor, an astronomer of his time, in this manner could accumulate information about the position and visibility of luminaries, and only then, with their help, made conclusions about their movements. This is significant as 
the most ancient bibliographical evidence about rock art in general. And this may be considered as the earliest evidence of antiquity and trustworthiness, reliability of the rock-carvings with astronomical content. Thus, the above mentioned citation of Shirakatsi and this petroglyph are witness to the origins of cosmological ideas in the Armenian Highland. ${ }^{12}$

Research history. Petroglyphs were first published and interpreted in Armenian scientific periodicals - in journal "Ararat", 1886, 1893.

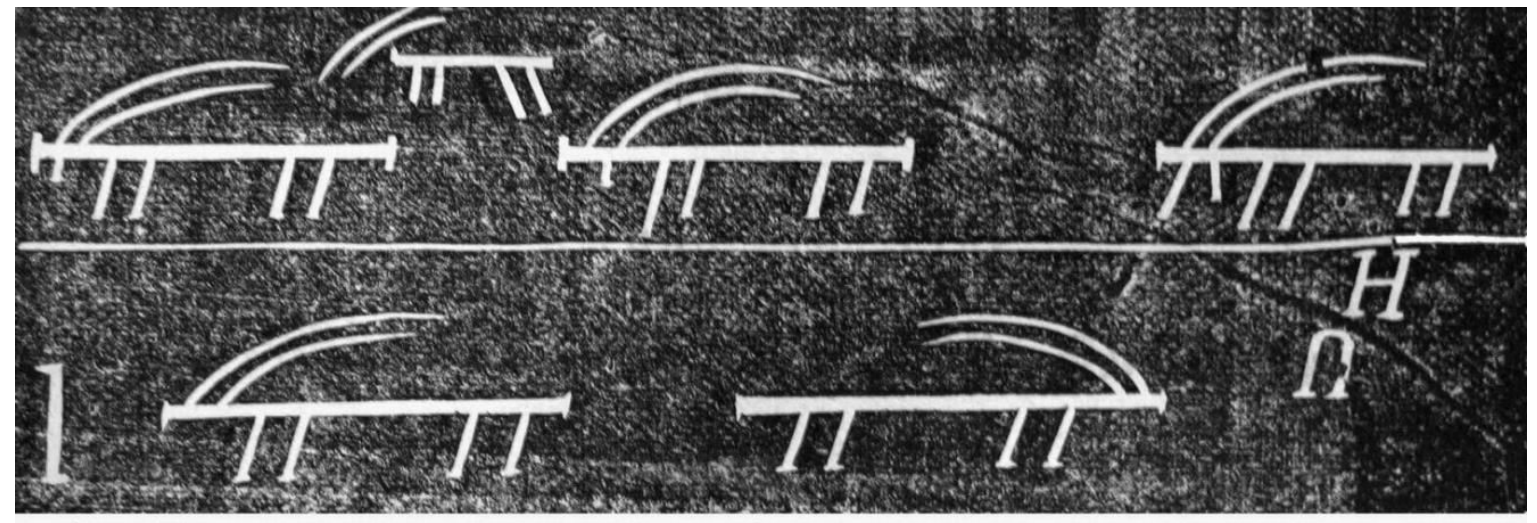

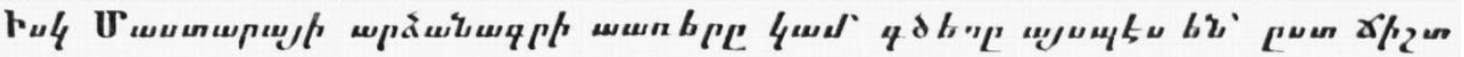

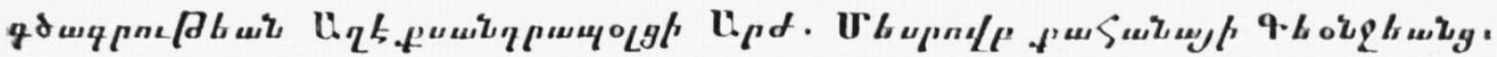

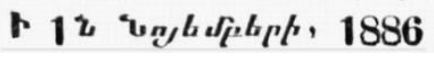

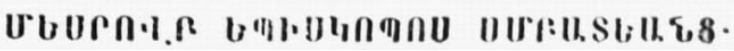

At the beginning of the 20th century M. Ter-Movsesian, A. Kalantar, Gr. Ghapantsyan investigated hundreds of petroglyphs on mt. Aragats, and L. Lisitsyan in Geghama mountains ${ }^{13}$. Since the second half of the century, archaeologists and amateurs found several thousand images in Syunik, Vardenis and Geghama Ridges ${ }^{14}$, and also in lowland areas. Later Armenian archaeologists H. Martirossyan, S.

\footnotetext{
${ }^{12}$ About the cosmological percepitions of Anania Shirakatsi see also in the works of E.Danielyan: Даниелян Э.Л., Армянские космографические труды VII в. о строении Вселенной, Ер., 1978;

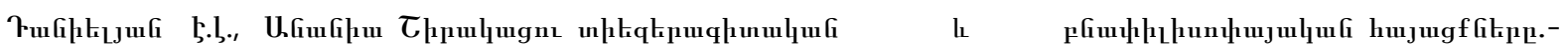

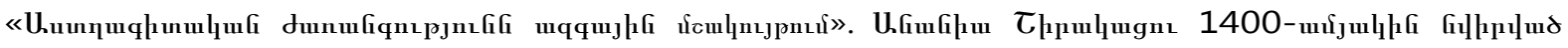

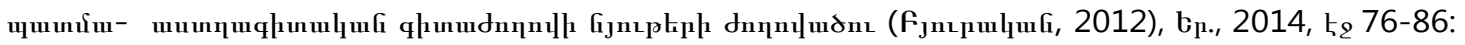

${ }^{13}$ About the cosmological percepitions of Anania Shirakatsi see also in the works of E.Danielyan: Даниелян Э.Л., Армянские космографические труды VII в. о строении Вселенной, Ер., 1978;

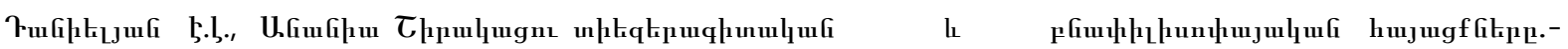

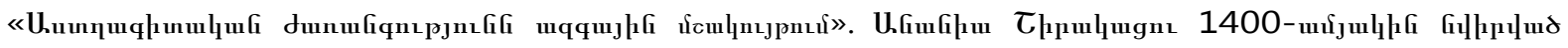

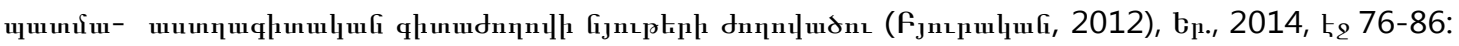

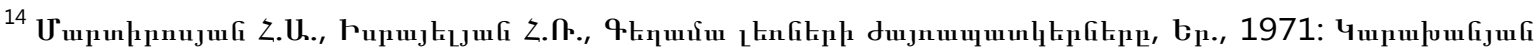

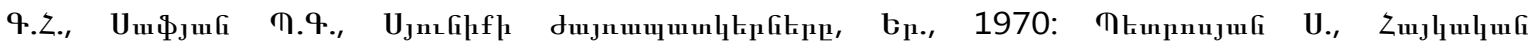

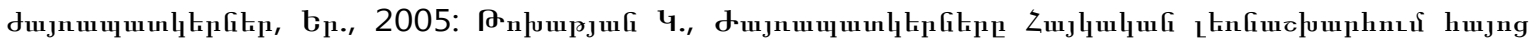

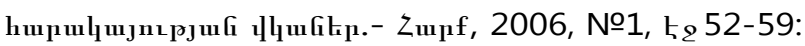


Sardaryan, G. Karakhanyan published four volumes of their studies (1320 copies of rock-carvings). This area of research is currently coordinated by the Institute of History and by "ARARA-T" (Armenian Rock Art Research Academy - Tir).

Conclusions. Thus, the creators of rock-art have possessed a unified ethno- cultural identity as it is evidenced by the thematic, stylistic and technical uniformity of the known monuments of the Armenian Highland. The thematic connection between rock-art and other spheres of Armenian culture is obvious, particularly with fine art and decorative-applied arts (ceramics, miniature, carpet weaving, weapons, national costume), with dance, theater, types of combat, vehicles, architecture, as well as with calendar, writing, folklore, and mythology. The same style of narration and drawing is observed in rock art and in the mentioned spheres of culture.

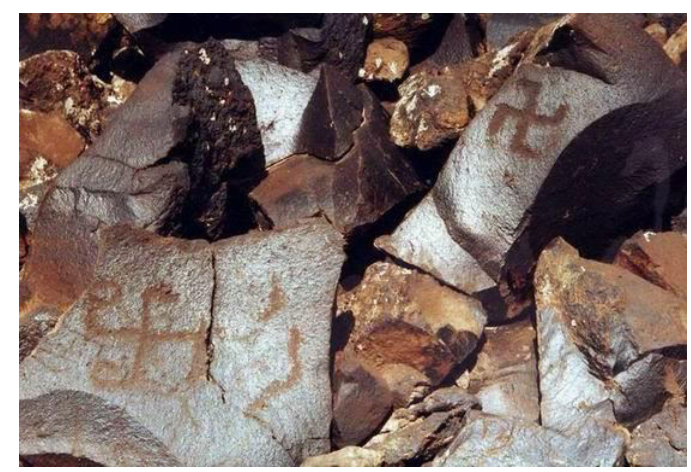

Petroglyph (Geghama mountains)

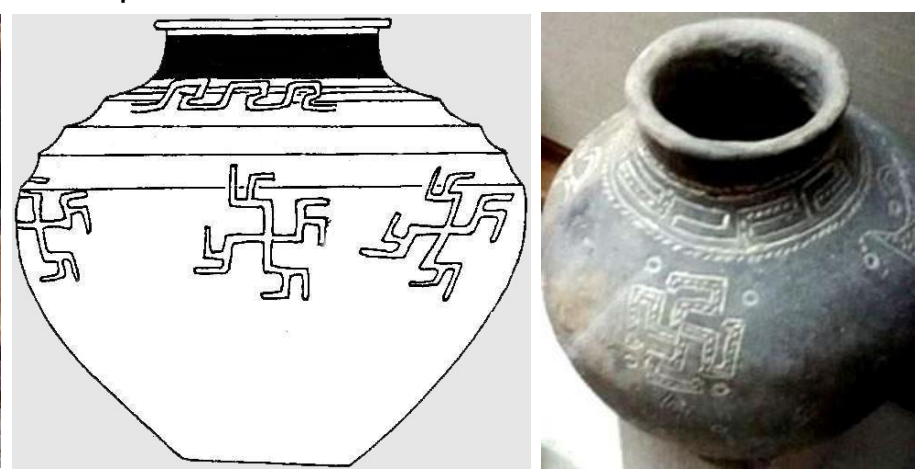

Ceramics (III millennia BC)

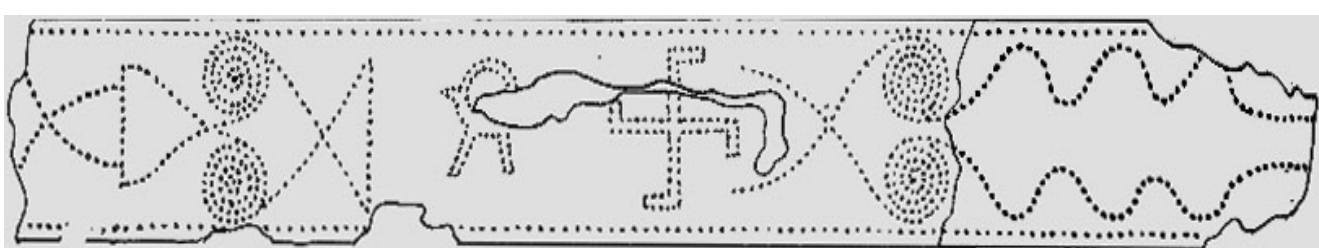

Bronze belt

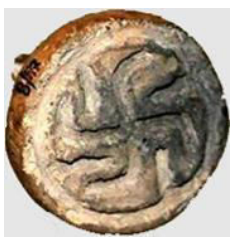

Stamp

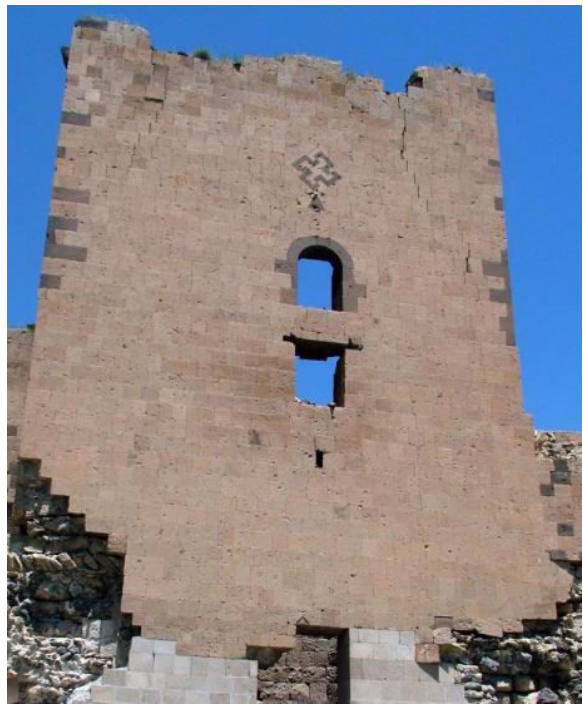

Ani (X century)

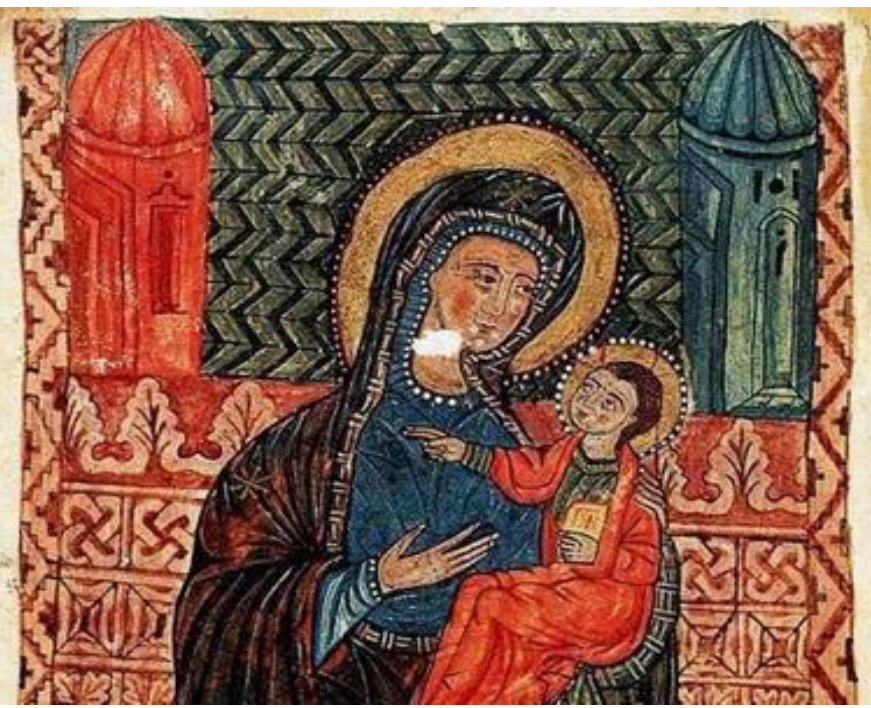

Miniature of Grigor Tatevatsi, 1378 


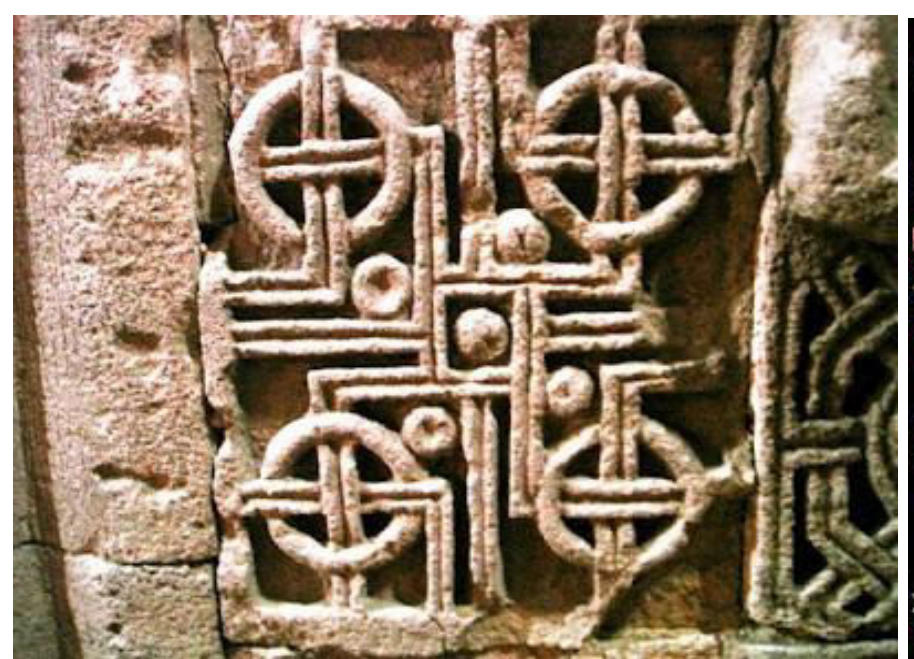

Khachqar

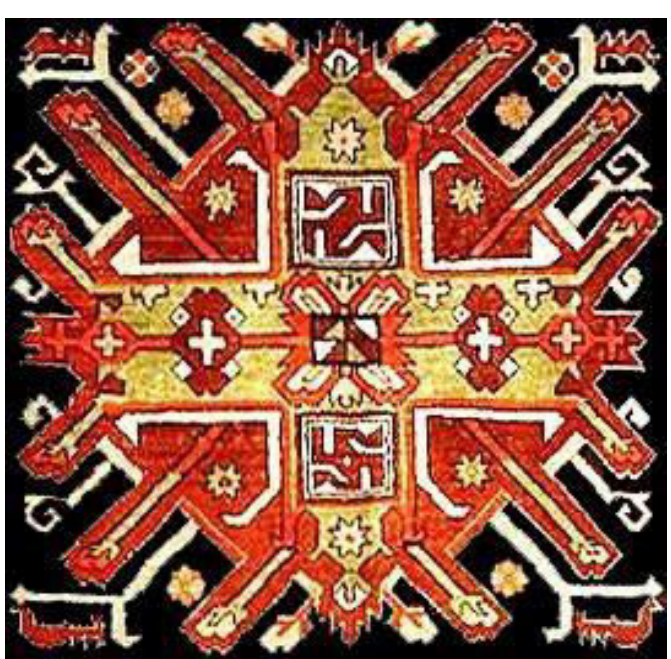

Carpet

The traditions of rock-art have been preserved in the Armenian Highland for millennia. Extension in time, succession and continuity of this sphere of culture is obvious. A striking evidence of this is the close thematic correlations of technology and art between the petroglyphs and other fields of culture (sculpture, lapidary inscriptions, construction and architecture) at different ages.

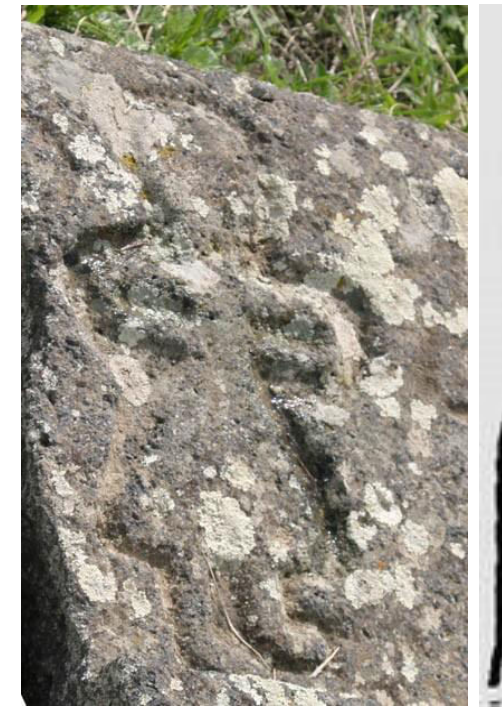

Tghmut in Aragatsotn

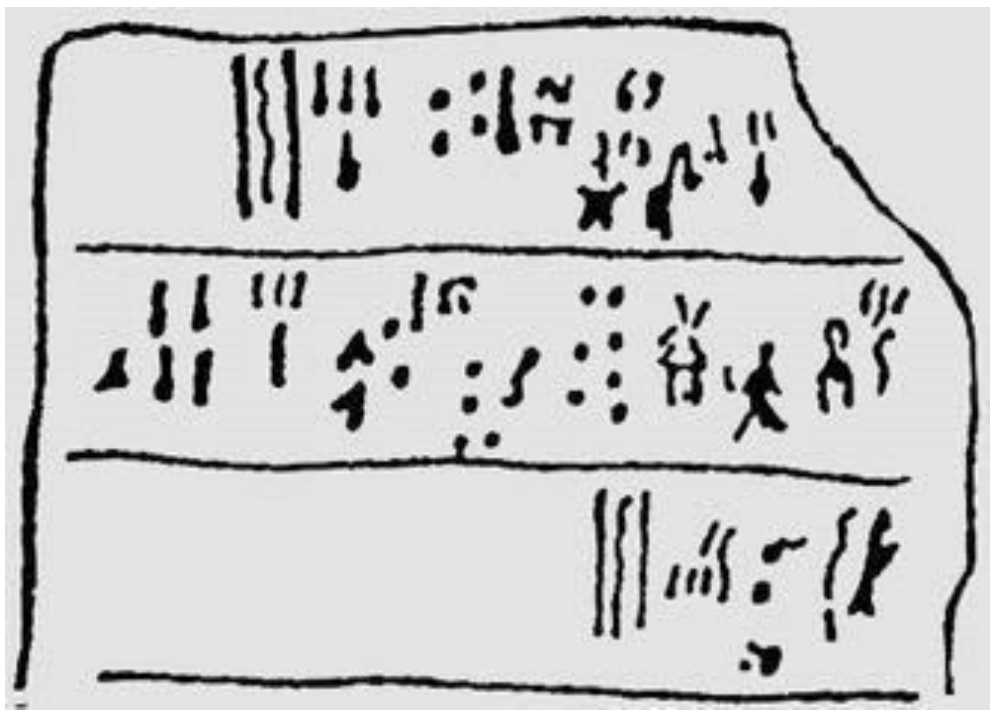

Mokhrablur in Van

Commonality of petroglyphs indicates the presence of a united worldview, of the same linguistic thinking, of a system of beliefs and pantheon, as well as of the beginning of centralized government - the elements of statehood. Culture, in all spheres of its manifestation, is distributed in the Armenian Highland almost equally, so it is presented as one entity for the reason that anthropological and cultural pictures had never been interrupted in the course of the time and space (about 400 
$\left.000 \mathrm{~km}^{2}\right)$.

The creators of petroglyphs led a sedentary life for the span of millennia that helped to create for generations. Accumulation and transmission of information by petroglyphs have provided viability and effectiveness of the individual and society through the preservation of knowledge, skills and traditions. This, in its turn, contributed to the preservation of the natural environment, the mentality of the society, and as a result, the security and the very existence of the people.

The Armenian Highland is a cradle of Rock-art. Adjacent to the Highland regions ancient rock carvings are almost completely absent, while in the Highland their high concentration and thematic diversity is observed.

Powerful ethnocultural impulses spread from the Armenian Highland. The tradition of rock art, its semantics and mastery of performance demonstrate radial distribution. There was a dissemination of worldview from the ancient centers of civilization in the form and by means of petroglyphs. Linguistic data concerning the concept of localization of the Indo-Europeans' homeland in the Armenian Highland $^{15}$, and theories systematizing numerous credible extra linguistic facts (archaeological, ethnographic, astronomical, calendar and general archaeological data) are evidence of the leading role of the deep rooted Armenian culture in Ancient World civilization.

Rock art was an original and primary traditional sphere of creation inherent to native Armenians, and in terms of time - also exclusive. Petroglyphs are the creative heritage of the millennia-old, indigenous Armenian nation of the Armenian Highland. 